\title{
Impact Testing of Simulated High-Level Waste Glass
}

\section{Canisters}

\author{
M. E. Peterson \\ J. M. Alzheimer \\ S. C. Slate
}

January 1985

*?:

Prepared for the U.S. Department of Energy under Contract DE $-A C 06-76 R L O 1830$

Pacific Northwest Laboratory

Operated for the U.S. Department of Energy

by Battelle Memorial Institute 


\section{DISCLAIMER}

This report was prepared as an account of work sponsored by an agency of the United States Government. Neither the United States Government nor any agency thereof, nor any of their employees, makes any warranty, express or implied, or assumes any legal liability or responsibility for the accuracy, completeness, or usefulness of any information, apparatus, product, or process disclosed, or represents that its use would not infringe privately owned rights. Reference herein to any specific commercial product, process, or service by trade name, trademark, manufacturer, or otherwise, does not necessarily constitute or imply its endorsement, recommendation, or favoring by the United States Government or any agency thereof. The views and opinions of aluthors expressed herein do not necessarily state or reflect those of the United States Government or any agency thereof.

\section{PACIFIC NORTHWEST LABORATORY operated by BATTELLE for the UNITED STATES DEPARTMENT OF ENERGY under Contract DE-AC06-76RLO 1830}

\begin{tabular}{|c|c|}
\hline \multicolumn{2}{|c|}{ Printed in the United States of America } \\
\hline \multicolumn{2}{|c|}{ Availabie from } \\
\hline \multirow{3}{*}{\multicolumn{2}{|c|}{$\begin{array}{c}\text { National Technical Information Service } \\
\text { United States Department of Commerce } \\
5285 \text { Port Royal Road } \\
\text { Springfield, Virginia } 22161\end{array}$}} \\
\hline & \\
\hline & \\
\hline \multirow{2}{*}{\multicolumn{2}{|c|}{$\begin{array}{l}\text { NTIS Price Codes } \\
\text { Microfiche A01 }\end{array}$}} \\
\hline & \\
\hline \multicolumn{2}{|c|}{ Printed Copy } \\
\hline & Price \\
\hline Pages & Codes \\
\hline $001-025$ & A02 \\
\hline $026-050$ & A.93. \\
\hline $051-075$ & $\mathrm{AOA}$ \\
\hline $076-100$ & A05 \\
\hline $101-125$ & 406 \\
\hline $126-150$ & A07 \\
\hline $151-175$ & A08 \\
\hline $176-200$ & $\mathrm{AO9}$ \\
\hline $201-225$ & $\mathrm{~A} 010$ \\
\hline $226-250$ & $\mathrm{~A} 011$ \\
\hline $251-275$ & $\mathrm{~A} 012$ \\
\hline $276-300$ & $\mathrm{~A} 013$ \\
\hline
\end{tabular}


IMPACT TESTING OF SIMULATED HIGH-LEVEL WASTE GLASS CANISTERS

M. E. Peterson

J. M. Alzheimer

S. C. Slate

January 1985

Prepared for

the U.S. Department of Energy

under Contract DE-AC06-76RLO 1830

Pacific Northwest Laboratory

Richland, Washington 99352 


\section{SUMMARY}

Three Savannah River Laboratory (SRL) reference high-1ever waste (HLW) canisters were subjected to impact tests at the Pacific Northwest Laboratory (PNL) in Richland, Washington, in June, 1983. The purpose of the test was to determine the integrity of the canister, nozzle, and final closure weld and to assess the effects of impacts on the glass. Two of the canisters were fabricated from 304L stainless steel and the third canister from titanium. The titanium canister underwent impact testing to provide input for a study regarding the mechanical feasibility of using titanium as a waste form container. In the impact tests a11 three canisters were oriented to provide the most severe stress to the canister upon impact. The glass fines in the stainless steel canisters were then characterized.

The titanium canister was subjected to two drops. The first drop was vertical from $9.14 \mathrm{~m}$ (30 ft) onto an unyielding surface with the bottom corner of the canister receiving the impact. No failure occurred during this drop. The second drop was vertical from $9.14 \mathrm{~m}$ (30 ft) onto an unyielding surface with the corner of the fill nozzle receiving the impact. A large breach in the canister occurred in the region where the fill nozzle joins the dished head.

The first stainless steel canister was dropped from $9.14 \mathrm{~m}$ (30 ft.) with the corner of the fill nozzle receiving the impact. The canister showed significant strain with no rupturing in the region where the fill nozzle joins the dished head. The second canister was dropped from $9.14 \mathrm{~m}$ (30 ft) with the bottom corner receiving the impact and also, dropped horizontally from $1.02 \mathrm{~m}$ (40 in.) onto an unyielding vertical solid steel cylinder $[15 \mathrm{~cm}$ (6 in.) dia. $x$ $46 \mathrm{~cm}$ (18 in.) high] in a puncture test. The bottorn drop did not damage the weld and the puncture test did not rupture the canister body. A helium leak test and dye penetrant test conducted on the weld regions revealed no leaks and no significant linear indications or cracks.

The glass particles in the damaged zone of these canisters were sampled and analyzed for particle size. A comparison was made $w$. th an SRL-supplied control canister in which no impact had occurred. The particle size distribution for the control canisters and the zones of damaged glass were determined 
down to 1.5 $\mu \mathrm{n}$. The quantity of glass fines, smaller than $10 \mu m$, which must be determined for transportation safety studies, was found to be the largest in the bottom-damaged zone. The total amount of fines smaller than 10 um after impact was less than $0.01 \mathrm{wt}$ of the total amount of glass in the canister. 


\section{ACKNOWLEDGMENTS}

The authors would like to acknowledge K. E. Eliason and L. L. Shotwell for their technical assistance. 


\section{CONTENTS}

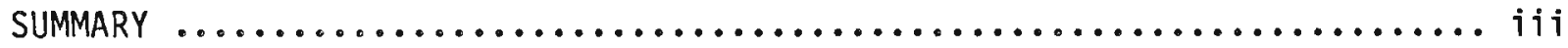

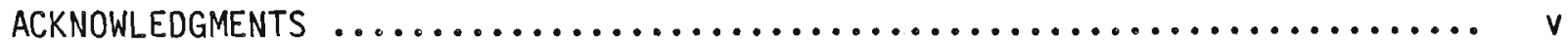

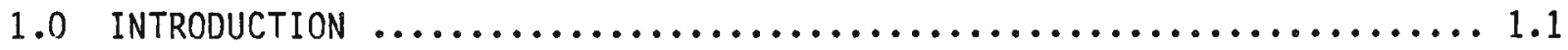

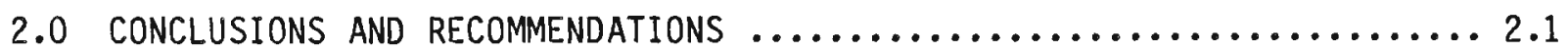

3.0 IMPACT TEST DESCRIPTION $\ldots \ldots \ldots \ldots \ldots \ldots \ldots \ldots \ldots \ldots \ldots \ldots \ldots \ldots \ldots \ldots \ldots \ldots \ldots . \ldots \ldots$

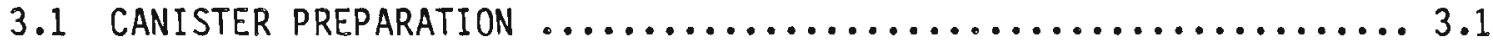

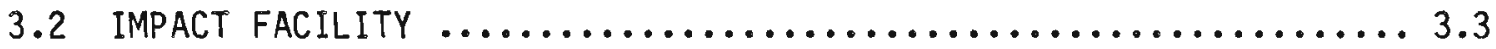

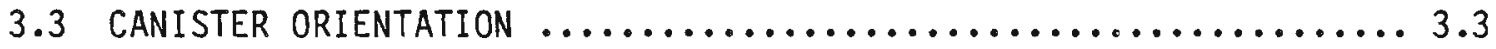

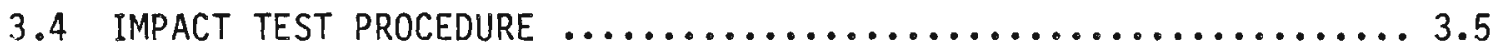

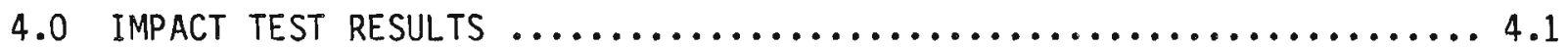

4.1 GENERAL OBSERVATIONS $\ldots \ldots \ldots \ldots \ldots \ldots \ldots \ldots \ldots \ldots \ldots \ldots \ldots \ldots . .1$

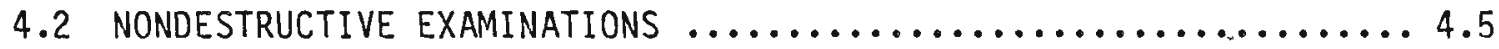

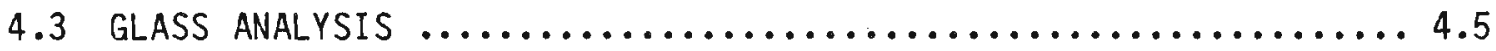

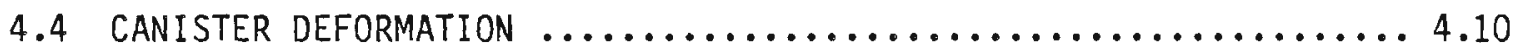

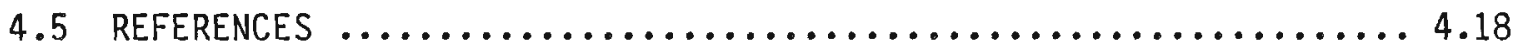




\section{FIGURES}

3.1 Three SRL Canisters Before Impact Tests $\ldots \ldots \ldots \ldots \ldots \ldots \ldots \ldots \ldots \ldots .2$

3.2 Bottom View of the Three SRL Canisters Before Impact Tests $\ldots \ldots \ldots . .3 .2$

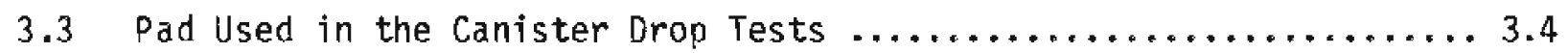

4.1 Fil1 Nozzle of Titanium Canister After Impact ................ 4.2

4.2 Bottom Impact Area of Titanium Canister After Impact ............ 4.2

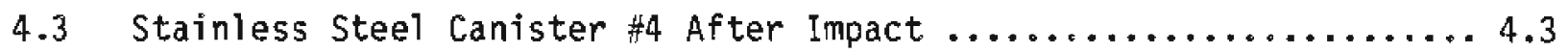

4.4 Bottom Area of Canister $\frac{\|}{\pi 5}$ After Impact $\ldots \ldots \ldots \ldots \ldots \ldots \ldots \ldots .4 .4$

4.5 Canister \#5 Body After Puncture Test .......................4.4

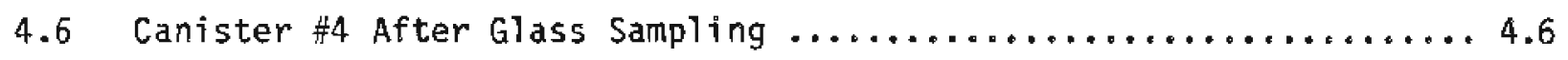

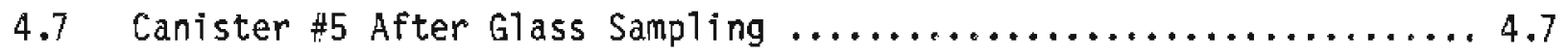

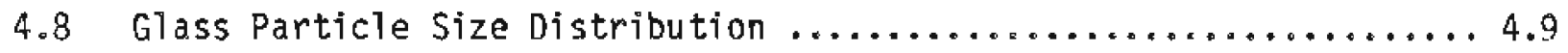

4.9 Log-Normal Plot of Glass Particle Size Distribution ............. 4.9

4.10 Strain Circle Grid on Canister Body ...................... 4.11

4.11 Strain Levels for the Titanium Canister for the Bottom

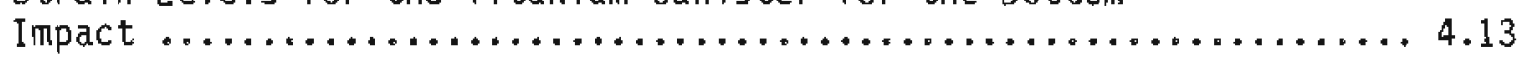

4.12 Strain Levels for the Titanium Canister for Strain Circle

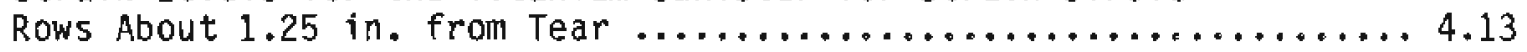

4.13 Strain Levels for the Titanium Canister for Strain Circle

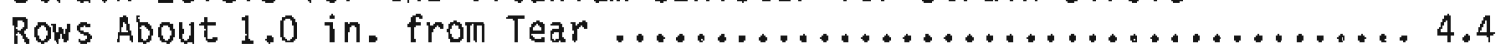

4.14 Strain Levels for the Titanium Canister for Strain Circle

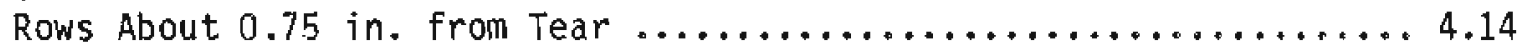

4.15 Strain Levels for the Titanium Canister for Strain Circle Rows About $0.5 \mathrm{in}$. from Tear ............................ 4.15

4.16 Strain Levels for the Titanium Canister for Strain Circle Rows About $0.25 \mathrm{in}$, from Tear .............................. 45

4.17 Strain Levels for Canister $\# 4$ for the Top Impact $\ldots \ldots \ldots \ldots \ldots \ldots . .16$

4.18 Strain Levels for Canister $\# 5$ for the Side Impact $\ldots \ldots \ldots \ldots \ldots \ldots, 4.17$

4.19 Strain Levels for Canister $\# 5$ for the Bottom Impact ............ 4.17 


\section{TABLES}

3.1 Physical Measurements of SRL Canisters $\ldots \ldots \ldots \ldots \ldots \ldots \ldots \ldots \ldots . \ldots . \ldots . \ldots$

3.2 Summary of Canister Orientations During Drop Tests ............... 3.4

4.1 Weight of Samples Obtained in Each Size Range .............. 4.7

4.2 Sub-38 um Particle Size Distribution ....................... 4.8

4.3 SRL Impact Tests Glass Analysis Summary $\ldots \ldots \ldots \ldots \ldots \ldots \ldots \ldots \ldots$ 


\subsection{INTRODUCTION}

Since 1975, the Pacific Northwest Laboratory (PNL) has conducted impact tests on canisters of simulated high-level waste (HLW) glass. The tests were conducted for two reasons, both related to the safe transport and handling of HLW canisters. The first reason was to demonstrate that an accidental impact would not create a breach that would allow leakage of glass from the canister. Analysis of the test results would have to show that the accident environment was not severe enough to alter the basic integrity of a standard canister. The second reason was to show that the inventory of glass particles in the respirable-size range ( $<10$ urm diameter) was less than the amount allowed to be released to the interior of the shipping cask. A small amount of respirable particles would imply that if a breach occurred, the consequences would not require a second level of containment.

PNi. carried out impact tests on full-size canisters containing simulated HLW glass in 1975, 1977, and 1981. Canisters were dropped from heights ranging from $1.02 \mathrm{~m}(40 \mathrm{in.)}$ to $31.7 \mathrm{~m}$ (104 ft) in different orientations to evaluate canister end pieces, fill nozzles, welds, and closure lids. The current designs for canisters are based, in part, on these test results and have proved to be very resistant to rupture during impacts.

The purpose of the 1983 test program, described here, was to measure the effects of impacts on Savannah River Laboratory (SRL) reference canisters and assess the resulting glass fracture. Two stainless steel canisters and a titanium canister were tested. 


\subsection{CONCLUSIONS AND RECOMMENOATIONS}

To accurately evaluate the impact performance of canisters, tests must be made using full-scale canisters containing simulated wastes. Two stainless steel reference canisters did not rupture during any of the impacts in the current test. The titanium (grade 2) canister ruptured during the impact on the nozzle. This test produced data from which the following conclusions and recommendations were made:

- Results showed that the reference design stainless steel canisters can withstand the impact conditions tested.

- Based on visual inspection, helium leak tests, and liquid dye penetrant tests, the stainless steel canisters were leak tight and no surface cracks resulted.

- Due to the rupturing of the titanium canister during the vertical top drop, further analysis of the design to determine modifications which would enable the canister to withstand impacts is recommended.

- The quantity of glass particles less than $10 \mu \mathrm{m}$ diameter, which is important in transportation safety, was sma11 (1ess than 0.01 wt\% of the total amount of glass in the canister).

- Based on a statistical analysis of the data, additional impact tests must be conducted in order to determine with high confidence the quantity of particles less than $10 \mu \mathrm{m}$ diameter.

- Based on surface strain measurements using strain circles, there was a considerable amount of allowable strain remaining before the stainless steel canisters would fail.

- Because strain measurements at the location of the tear on the titanium canister were not possible, the strain level at which rupture occurred was not obtained.

- The stainless steel canisters were able to undergo the impacts without rupturing because of the high ductility of stainless steel and the ability of the canister design to absorb impact energy. 


\subsection{IMPACT TEST DESCRIPTION}

This report is divided into two sections: Impact Test Description, and Impact Test Results. The impact test description section presented below discusses the canister preparation, the impact test facility, the canister orientation, and impact test procedure.

\subsection{CANISTER PREPARATION}

SRL supplied to PNL the reference canisters filled with simulated waste glass at reference pour conditions (Baxter, 1983). The canisters were $0.61 \mathrm{~m}$ (24 in.) in diameter with a length of $3.05 \mathrm{~m}(10 \mathrm{ft})$. The ends were dished and flued with a single flange design used for the fill nozzle of the 304L stainless steel canisters. The fill nozzle on the titanium canister was a double flange design.

Measurements of the weight, length, diameter, and center of gravity location were obtained for each canister. These measurements are shown in Table 3.1. The SRL canisters were numbered 3, 4, and 5 with the titanium canister designated number 3.

The canisters, prior to the impact test, are shown in Figures 3.1 and 3.2 . The patterns apparent on the nozzle, mid-line region, and bottom impact area are strain circles used to measure strain resulting from the canister drop. These strain circles, which are deposited on the surface of the canisters using an electrochemical process, were placed on the canisters in regions of

\section{TABLE 3.1. Physical Measurements of SRL Canisters}

\begin{tabular}{|c|c|c|c|c|c|c|c|c|}
\hline \multirow{2}{*}{$\begin{array}{c}\text { Canister } \\
\text { No. }\end{array}$} & \multicolumn{2}{|c|}{ Weight } & \multicolumn{2}{|c|}{ Diameter } & \multicolumn{2}{|c|}{ Length } & \multicolumn{2}{|c|}{$\begin{array}{c}\text { Bottom to Center } \\
\text { of Gravity }\end{array}$} \\
\hline & $\mathrm{Kg}$ & (16) & $\mathrm{m}$ & $(f t)$ & $m$ & $(\mathrm{ft})$ & $\pi$ & $(\mathrm{ft})$ \\
\hline 3 & 1849 & $(4076)$ & 0.61 & (2) & 3.05 & (10) & 1.81 & $(3.88)$ \\
\hline 4 & 2189 & (4825) & 0.61 & (2) & 3.05 & (10) & 1.27 & $(4.16)$ \\
\hline 5 & 2413 & $(5320)$ & 0.61 & (2) & 3.05 & (10) & 1.38 & $(4.52)$ \\
\hline
\end{tabular}




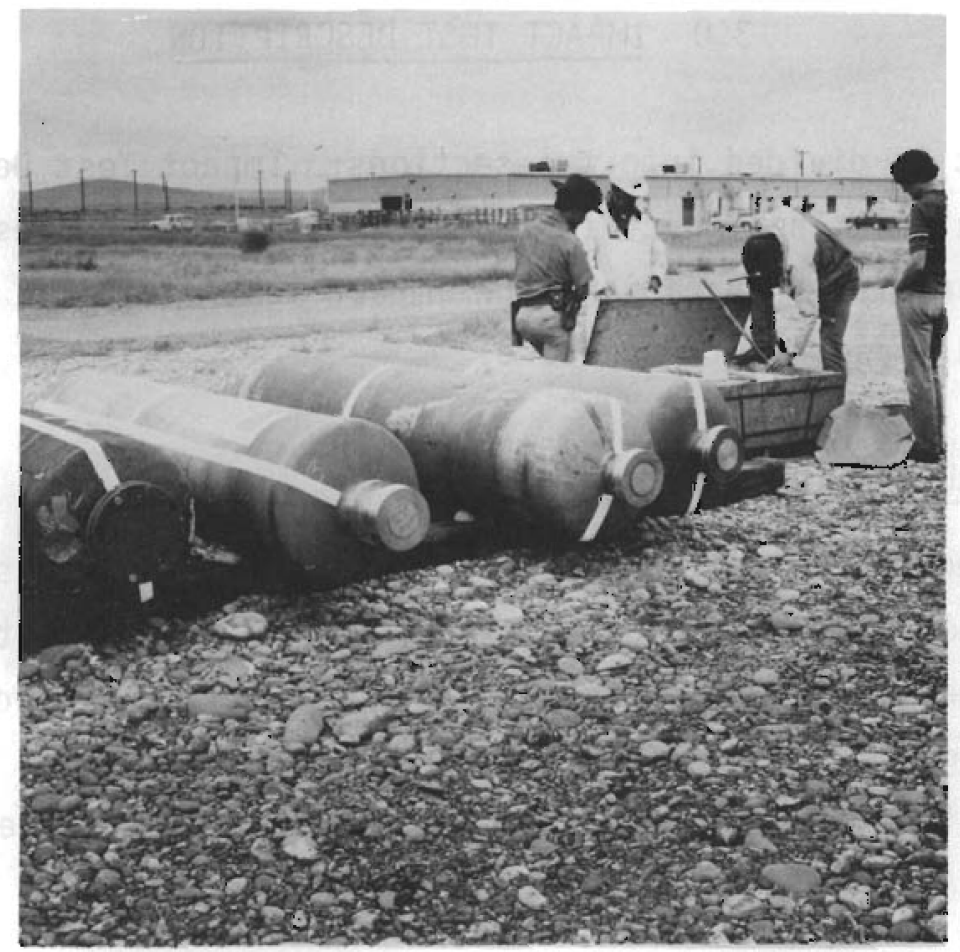

FIGURE 3.1. Three SRL Canisters Before Impact Test

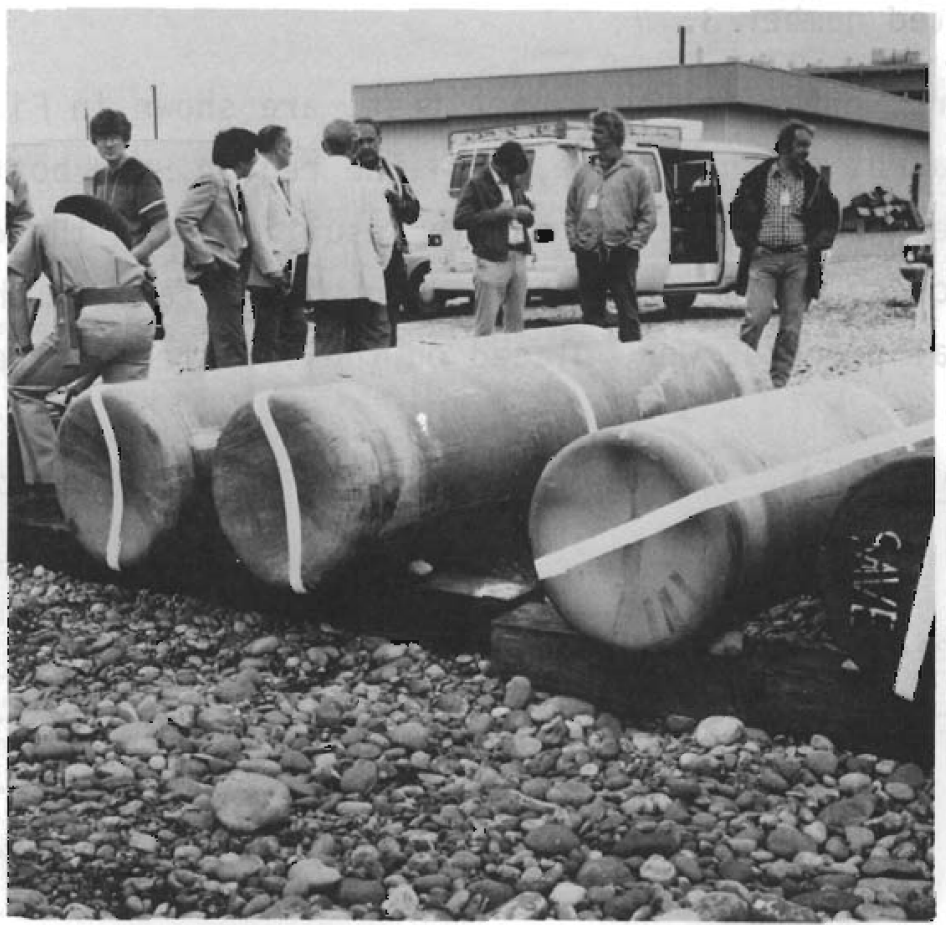

FIGURE 3.2. Bottom View of the Three SRL Canisters Before Impact Tests 
anticipated high strain. The initial circle diameters were nominally $5.08 \mathrm{~mm}$ $(0.20 \mathrm{in.})$. After the tests, the diameters of the circles were measured to calculate the effective strain.

\subsection{IMPACT FACILITY}

A truck-mounted crane was used to hoist the canister the specified distance above the impact pad. A conventional cable choker was fastened around the canister and positioned to achieve the desired vertical and horizontal orientation of the canister. The cable choker was attached to the lifting cable by a latching hook that could be released by a lanyard from the ground. This drop technique allowed good position control so the canister could be made to impact in the desired orientation. A measured rope was loosely taped to the lowest point of the canister to indicate the drop height. This rope was pulled loose prior to dropping the canister.

The impact pad consisted of a $3.05 \mathrm{~m}(10 \mathrm{ft})$ by $3.05 \mathrm{~m}(10 \mathrm{ft})$ by $1.22 \mathrm{~m}$ $(4 \mathrm{ft})$ thick slab of reinforced concrete with a $1.52 \mathrm{~m}(5 \mathrm{ft})$ by $2.13 \mathrm{~m}(7 \mathrm{ft})$ by $0.18 \mathrm{~m}(7 \mathrm{in.})$ thick steel plate on top. The mass of the pad was approximately 10 times the mass of a single canister which satisfies guidelines for an unyielding surface. For the puncture test, the canisters were dropped on a vertical solid steel cylinder $[0.15 \mathrm{~m}$ (6 in.) diameter $\times 0.46 \mathrm{~m}$ (18 in.) 1ong] which was bolted onto the steel plate. Behind the impact pad was a checkerboard pattern backdrop which was used in conjunction with high speed photography for estimating distances during the moment of impact. The checkerboard squares were $0.30 \mathrm{~m}(1 \mathrm{ft})$ by $0.30 \mathrm{~m}(1 \mathrm{ft})$. The impact pad is shown in Figure 3.3 .

\subsection{CANISTER ORIENTATION}

The canisters were oriented and dropped so that the most severe impact, with the center of gravity located over the impact point, was realized. The titanium canister (\#3) experienced impacts to both the top and the bottom. The \#4 stainless steel canister experienced impact to the top and the \#5 stainless steel canister underwent impacts to the bottom and side. A summary of the canister orientations is shown in Table 3.2. The top drop was from $9.14 \mathrm{~m}$ 


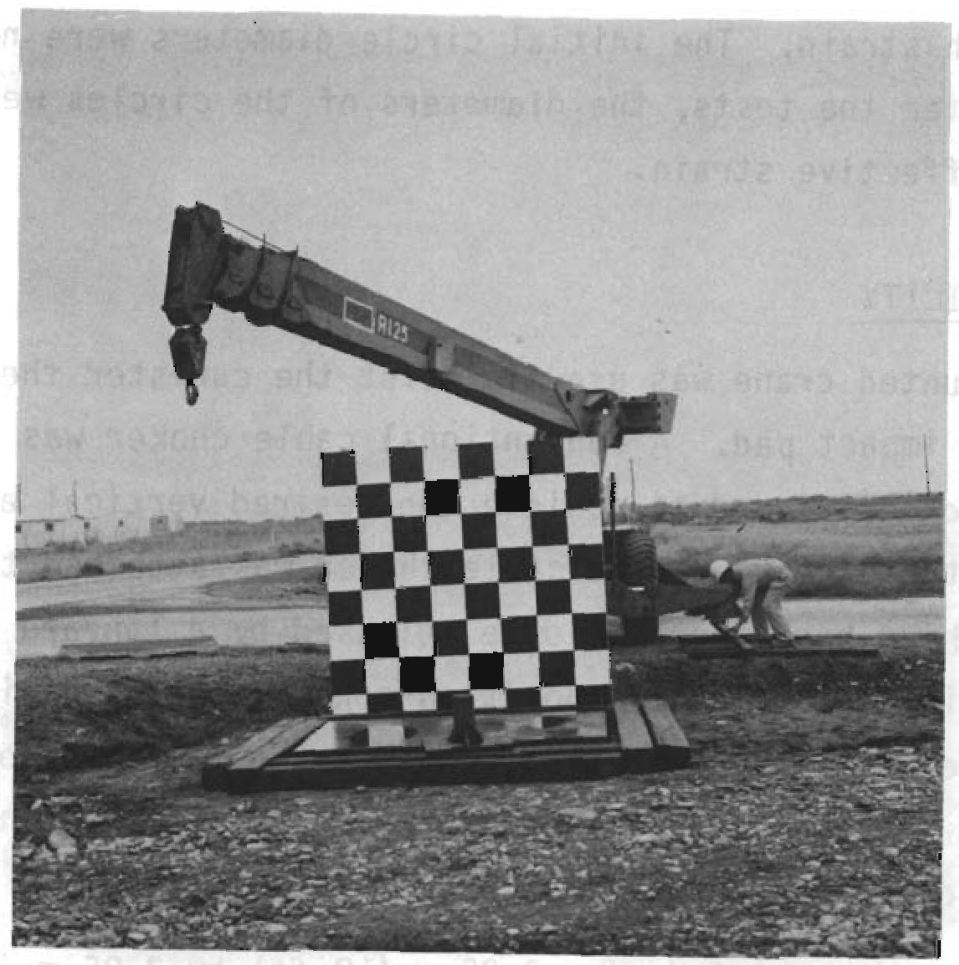

FIGURE 3.3. Pad Used in the Canister Drop Tests.

TABLE 3.2. Summary of Canister Orientations During Drop Tests

\begin{tabular}{|c|c|c|c|}
\hline $\begin{array}{c}\text { Canister } \\
\text { No. }\end{array}$ & Material & Impact Area & Angle $\mathrm{e}^{(\mathrm{a})}$ \\
\hline 3 & Ti & $\begin{array}{c}\text { Top } \\
\text { Bottom }\end{array}$ & $4^{\circ}$ \\
\hline 4 & $304 \mathrm{LSS}$ & Top & $4^{\circ}$ \\
\hline \multirow[t]{2}{*}{5} & $304 \mathrm{~L} S \mathrm{~S}$ & Bottom & $11^{\circ}$ \\
\hline & & Side & $90^{\circ}$ \\
\hline
\end{tabular}

(a) Angle as measured from the vertical axis. This angle was calculated such that the center of gravity was located over the desired impact point. 
(30 ft) onto the fill nozzle of the canister with the corner of the nozzle receiving the impact. The side drop was from $1.02 \mathrm{~m}(40 \mathrm{in}$.) onto the $0.15 \mathrm{~m}$ ( 6 in.) diameter cylinder with the center of gravity over the impact point. The bottom drop was from $9.14 \mathrm{~m}(30 \mathrm{ft})$ with the bottom corner receiving the impact. The proper orientations of each canister were achieved and the desired point of impact realized.

\subsection{IMPACT TEST PROCEDURE}

As previously mentioned, a conventional cable choker was fastened to each canister and adjusted until the correct drop angle was achieved. The canister was then raised up to the desired drop height using a rope to indicate the correct distance. This rope was then pulled loose prior to dropping the canister. Upon a signal, the latching hook was released by pulling the lanyard allowing the canister to drop.

The titanium canister (\#3) was dropped first in each orientation followed by the stainless steel canisters. Each drop was recorded with video tape, high-speed film, and still photographs. Immediate visual observations and still photography were carried out on the impacted canisters. Later, the highspeed film was examined to confirm that the correct orientation for each drop was realized. The strain experienced by the canister was evaluated by the distortion of the strain circles at the impact points.

After impact testing, the canisters were transported to separate facilities for the helium leak test of canisters \#4 and \#5, dye penetrant test of canister \#5, and strain circle analysis of all three canisters. 


\subsection{IMPACT TEST RESULTS}

Included in this section on impact test results are the following areas: general observations, nondestructive examinations, glass analysis, and canister deformation.

\subsection{GENERAL OBSERVATIONS}

The first canister tested was the titanium canister which was dropped from $9.14 \mathrm{~m}(30 \mathrm{ft})$ onto the bottom corner and then 1ater dropped from $9.14 \mathrm{~m}$ (30 ft) onto the corner of the fill nozzle. After the initial impact on the bottom corner, the canister rebounded and landed on its side. The deformation of the bottom was asymmetric. After the initial nozzle impact, the canister rebounded and hit three more times before landing on its side. As a result of the drop on the fill nozzle, a large rupture occurred in the shoulder on the side opposite the impact point. The rupture appeared to tear as a result of shearing strains as opposed to a crack due to tensile strains. The impact on the corner of the nozzle forced the nozzle to deform to one side, which put a large strain on the shoulder. Figures 4.1 and 4.2 show the damage to the top and bottom of the canister.

The \#4 stainless steel canister was dropped from $9.14 \mathrm{~m}(30 \mathrm{ft})$ onto the corner of the fill nozzle. The nozzle and head were deformed into the canister with no rupture occurring. The deformation was symmetric. A helium leak test was performed on the impact area including all three welds and no detectable leak was found. Figure 4.3 shows this canister after impact.

The stainless steel canister \#5 was dropped from $9.14 \mathrm{~m}$ (30 ft) onto the bottom corner and dropped from $1.02 \mathrm{~m}$ (40 in.) horizontally on its side onto the $0.15 \mathrm{~m}$ (6 in.) diameter cylinder. After the initial impact on the bottom corner, the canister rebounded and landed on its side. The deformation at the bottom was asymmetric. After the initial impact on the canister body, the canister rebounded approximately four times before temporarily resting on the cylinder and then landing on its side. The canister did not rupture as a result of this impact. The bottom impact area and the bottom weld of the canister were subjected to a helium leak test and dye penetrant test to determine 


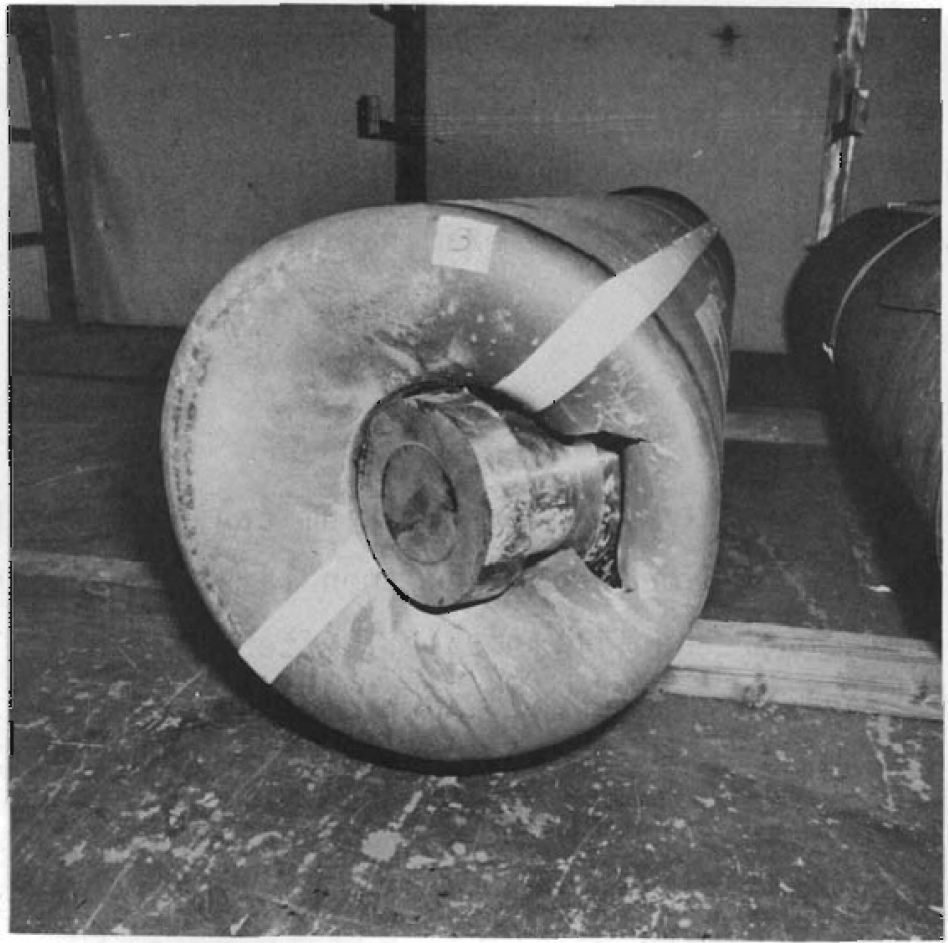

IGURE 4.1. Fill Nozzle of Titanium Canister After Impact

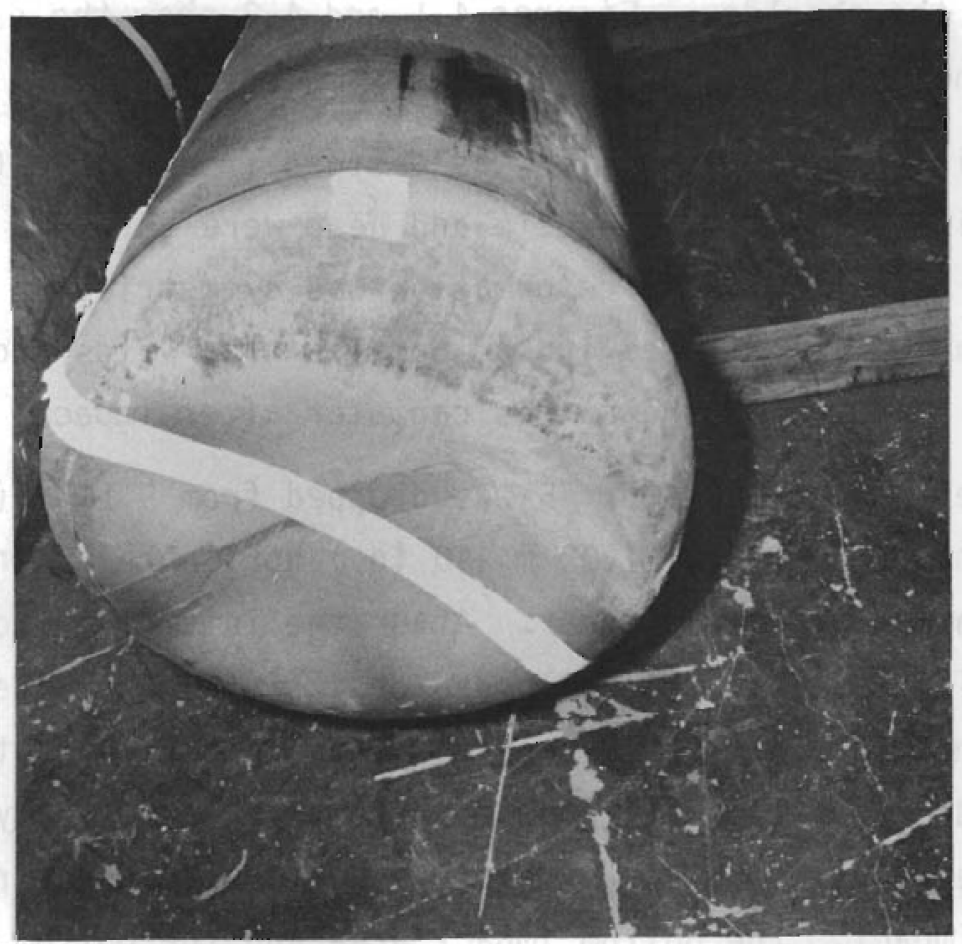

FIGURE 4.2. Bottom Impact Area of Titanium Canister After Impact 


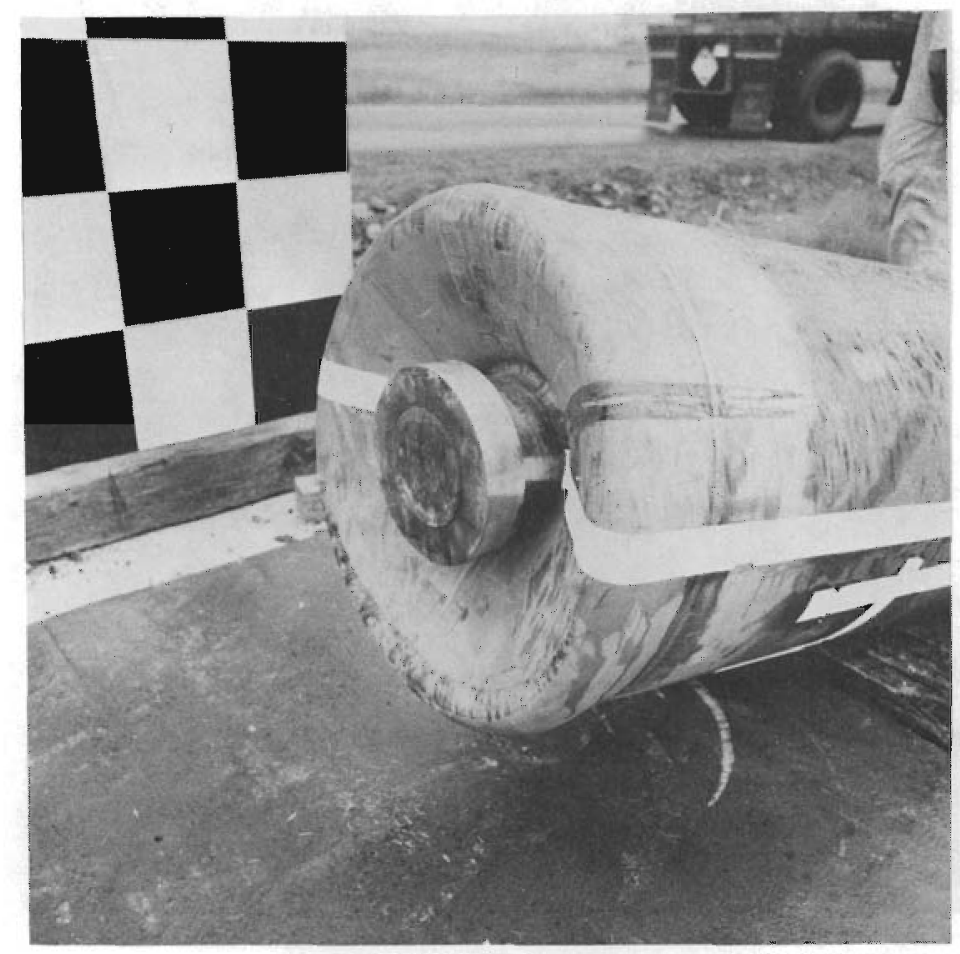

FIGURE 4.3. Stainless Steel Canister \#4 After Impact

if the canister was leak tight and if any cracks were present. No detectable leaks were found and no significant cracks appeared in the dye penetrant test. Figures 4.4 and 4.5 show the impacted areas.

The stainless steel canisters deformed with no ruptures occurring whereas, the titanium (grade 2) canister ruptured as a result of the nozzle impact. The difference in performance of the two canisters is partially due to the differences in mechanical properties, specifically the ductility of the two metals. The 304L stainless steel is more ductile than titanium and, therefore, will deform to a greater extent before rupture occurs. A typical value for the elongation to failure for grade 2 titanium is $17 \%$ and the value for $304 \mathrm{~L}$ stainless steel is 56\% (Metals Handbook 1978). Another possible reason for the difference in performance of the canister was that the canister nozzle designs were different. However, in 1981 PNL conducted impact tests on two stainless steel canisters with a fill nozzle design similar to the titanium canister and no failure occurred. The exact cause for the failure of the titanium canister 


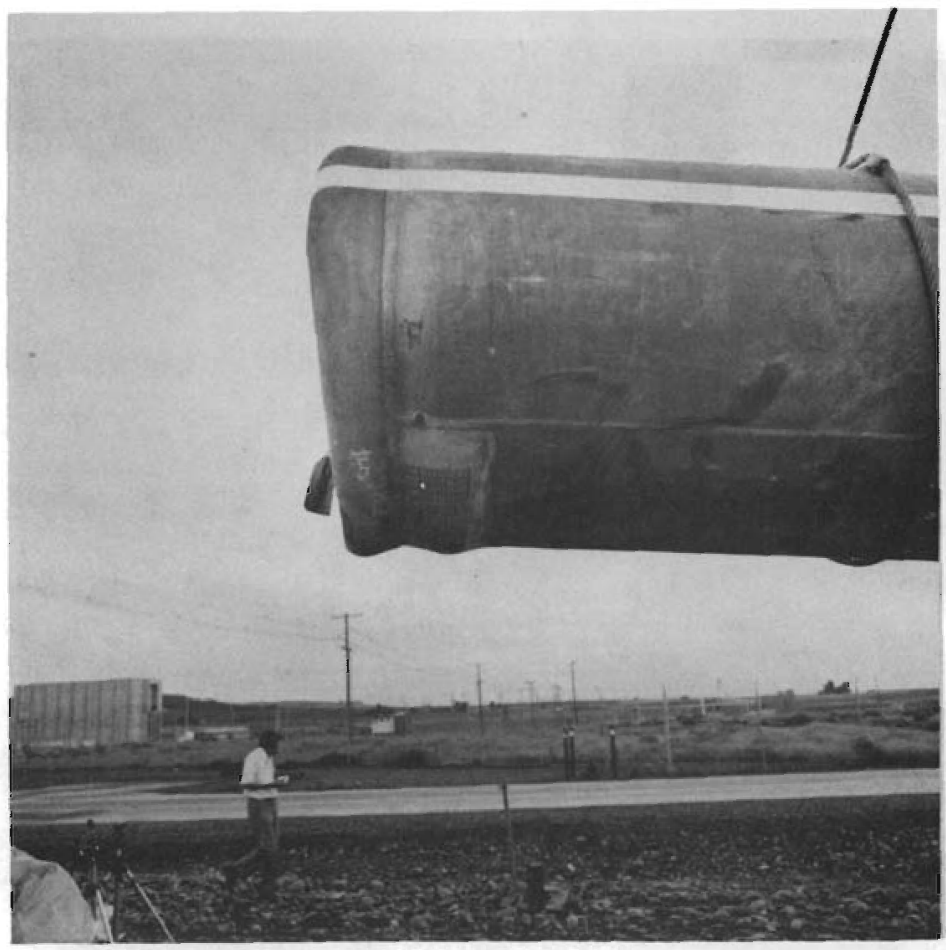

FIGURE 4.4. Bottom Area of Canister \#5 After Impact

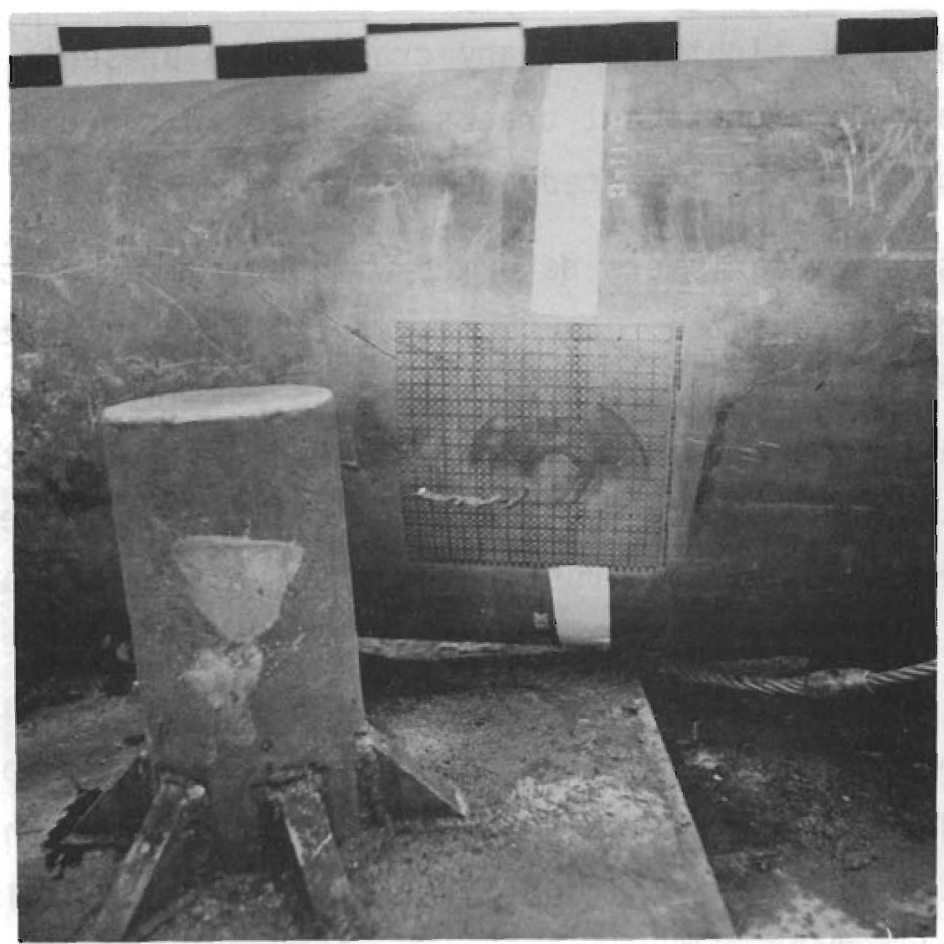

FIGURE 4.5. Canister \#5 Body After Puncture Test 
was not determined. Further analysis of the titanium design should be conducted to determine modifications which would enable the titanium canister to withstand impacts.

\subsection{NONDESTRUCTIVE EXAMINATIONS}

The stainless steel canisters were subjected to a helium leak test and dye penetrant test. Canister \#4 underwent a helium leak test and canister \#5 underwent a helium leak test and liquid dye penetrant test. The procedures for the helium leak test and dye penetrant test were done in accordance with ASME Sections III and $v$. The purpose of these tests was to determine if the weld and impact area were leak tight and if any surface cracks existed.

The helium leak tests were performed first. Heavy plastic was secured to the canister in all areas to be examined to isolate the area of interest from the atmosphere. The canisters were then evacuated and helium was put into the canister at a standard rate of $2.2 \times 10^{-8} \mathrm{~atm} \mathrm{cc} / \mathrm{sec}$. This was used to calibrate the mass spectrometer. The instrument sensitivity was $\left(4.5 \times 10^{-10} \mathrm{~atm}\right.$ $\mathrm{cc} / \mathrm{sec}$ )/scale division. Then the canisters were leak tested. Helium was injected into the plastic around all regions and the mass spectrometer was used to detect any helium leaking into the canister. No leaks were detected on canister \#4 or \#5. A leak rate of $1 \times 10^{-5} \mathrm{~atm} \mathrm{cc} / \mathrm{sec}$ has been proposed as the necessary level for transportation and final disposal (ONWI, 1983).

The next nondestructive examination was the liquid dye penetrant test on canister \#5. No indications of cracks were found on the canister areas examined which included the welds and surfaces on both sides of the welds. The first step of the procedure was to clean the area under examination with acetone and wipe it dry. A liquid penetrant was then brushed on the surface and was wiped off after remaining on the surface for at least 10 minutes. A developer was brushed on and after drying the results were determined by visual examination.

\subsection{GLASS ANALYSIS}

After the impacts and nondestructive testing, sections of stainless steel were removed from canisters \#4 and \#5 to expose large areas of glass near the 
impact area. The glass was sampled and analyzed to determine the particle size distribution and specifically the quantity of particles in the respirable size range (1ess than $10 \mu \mathrm{m}$ ). Figures 4.6 and 4.7 show the canisters after sampling was completed. Control samples of glass from the top and bottom regions of non-impacted canisters were supplied by SRL. Table 4.1 lists the ranges of the particle sizes which were analyzed and the weight of each sample. Initially all of the glass fines were screened into the ranges shown in Table 4.1 . The $+75 \mathrm{~mm}$ and $-75+25 \mathrm{~mm}$ ranges were hand sorted. The remaining size characteristics were determined by using standardized sieves. The samples in each range were then weighed. A representative sample of the sub-38 um material was obtained for analysis using a HIAC, which is an instrument that uses a laser to size and count the particles. Two samples, designated $A$ and $B$, of the sub-38 $\mu \mathrm{m}$ material were analyzed and the results are shown in Table 4.2 in a size distribution by weight percent.

The glass particle size distribution is shown in Figures 4.8 and 4.9 . Figure 4.8 shows the particle size distribution in the as-measured condition

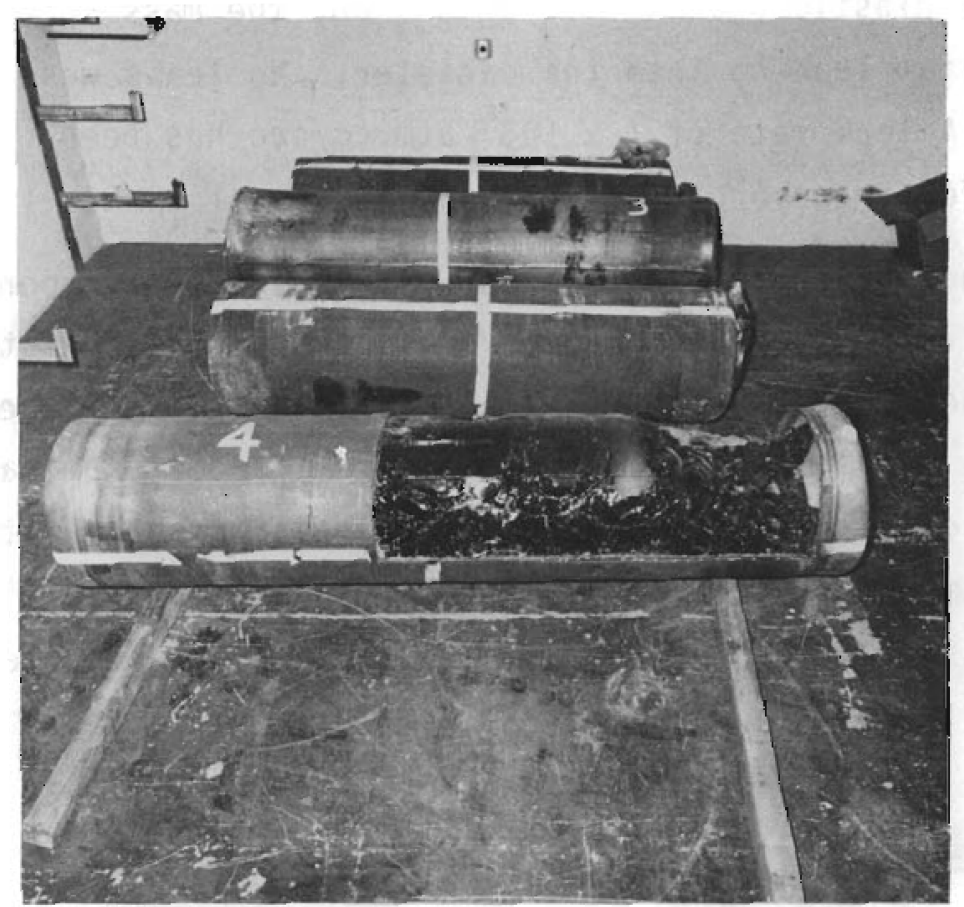




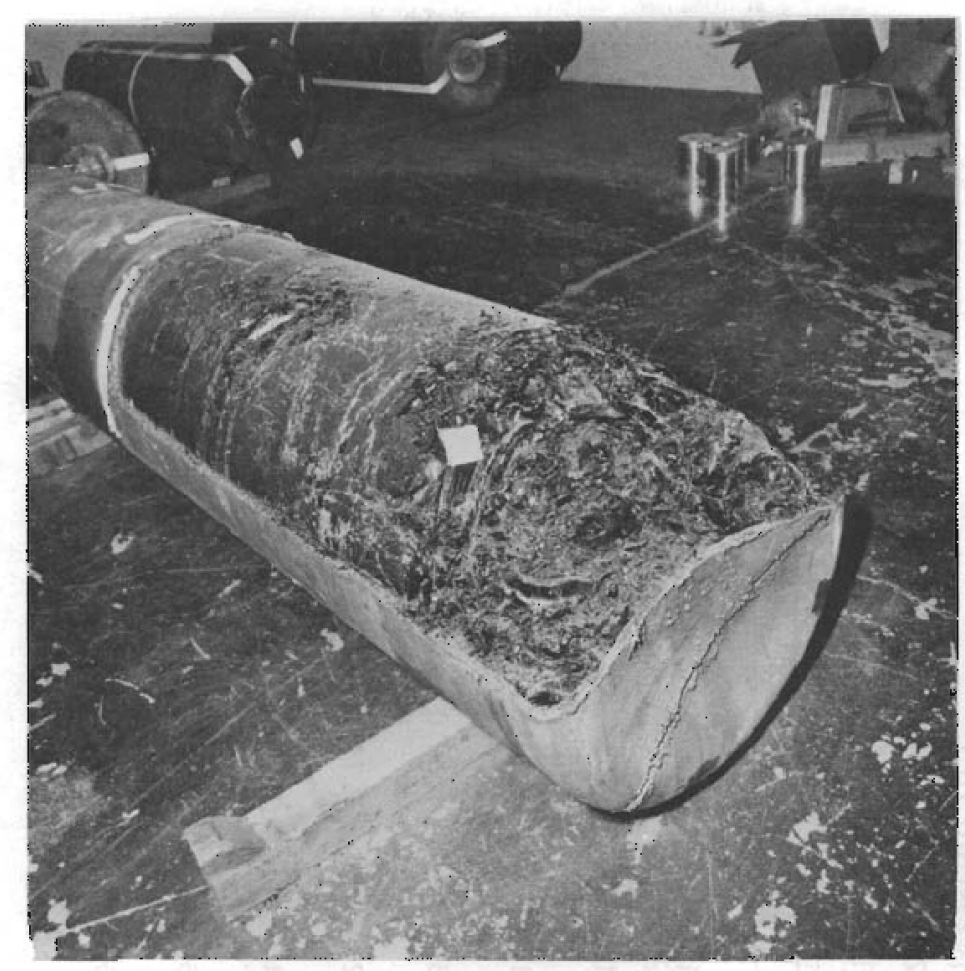

FIGURE 4.7. Canister \#5 After Glass Sampling

TABLE 4.1. Weight of Samples Obtained in Each Size Range

\begin{tabular}{|c|c|c|c|c|c|c|}
\hline \multirow[b]{2}{*}{ Size Range } & \multicolumn{6}{|c|}{ Weights (gms) } \\
\hline & $\begin{array}{l}\text { Control } \\
\text { Bottom }\end{array}$ & $\begin{array}{c}\text { Control } \\
\text { Top } \\
\end{array}$ & $\begin{array}{c}\text { \#4 } \\
\text { Top Drop } \\
\end{array}$ & $\begin{array}{c}\# 5 \\
\text { Side Drop } \\
\end{array}$ & $\begin{array}{c}\# 5 \\
\text { Bottom } \\
\text { Drop }\end{array}$ & $\begin{array}{c}\text { \#5 } \\
\text { Bottom } \\
\text { Corner }\end{array}$ \\
\hline$+75 \mathrm{~mm}$ & 65,000 & 72,000 & 301 & --- & --- & -- \\
\hline$-75+25 \mathrm{~mm}$ & 89,000 & 92,700 & 1,550 & 2,790 & 4,688 & --- \\
\hline$-25+13 \mathrm{~mm}$ & 14,784 & 14,300 & 374 & 1,904 & 4,003 & 987 \\
\hline$-13+8 \mathrm{~mm}$ & 5,019 & 3,313 & 196 & 2,263 & 4,706 & 1,478 \\
\hline$-8+2 \mathrm{~mm}$ & 3,600 & 3,206 & 210 & 3,829 & 8,114 & 6,450 \\
\hline$-2+1 \mathrm{~mm}$ & 420 & 308 & 32.1 & 796 & 1,790 & 2,662 \\
\hline$-1+0.5 \mathrm{~mm}$ & 195 & 164 & 12.9 & 350 & 933 & 2,033 \\
\hline$-500+212 \mu m$ & 116 & 91.6 & 5.7 & 162 & 515 & 1,427 \\
\hline$-212+106 \mu \mathrm{m}$ & 48.7 & 50.3 & 2.1 & 54.3 & 206 & 763.7 \\
\hline$-106+75,1 \mathrm{~m}$ & 17.5 & 12.8 & 0.3 & 14.6 & 56.3 & 116.0 \\
\hline$-75+38 \mu m$ & 27.5 & 17.0 & 0.1 & 17.9 & 71.4 & 195.0 \\
\hline$-38 \mu \mathrm{m}$ & 34.6 & 7.4 & 0.3 & 8.9 & 42.7 & 163.2 \\
\hline TOTAL WEIGHT & $178,262.3$ & $186,170.1$ & $2,684.5$ & $12,189.7$ & $25,125.4$ & $16,274.9$ \\
\hline
\end{tabular}




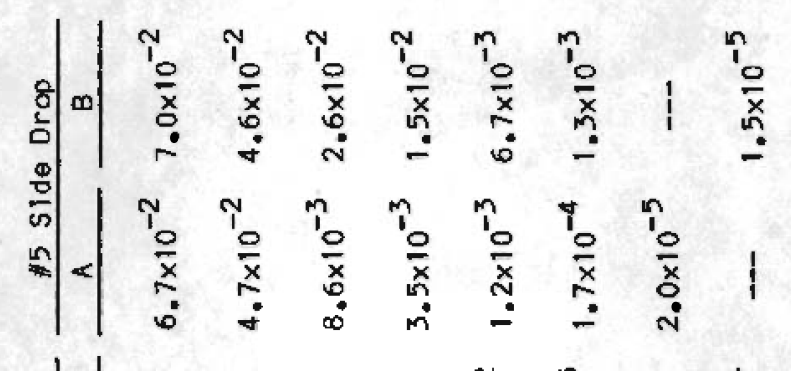

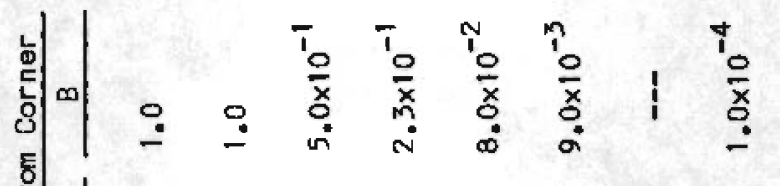

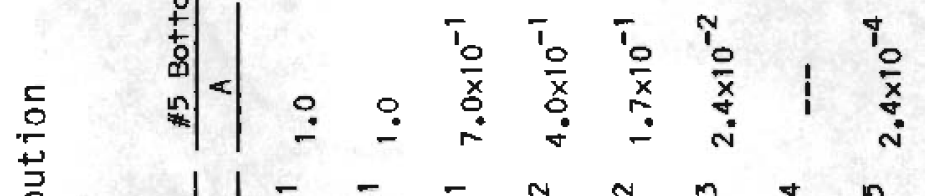

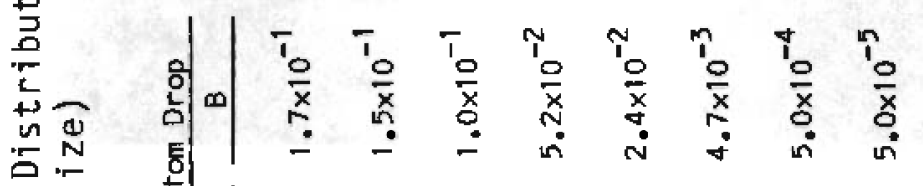

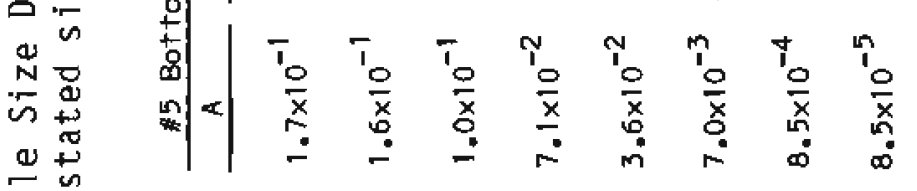

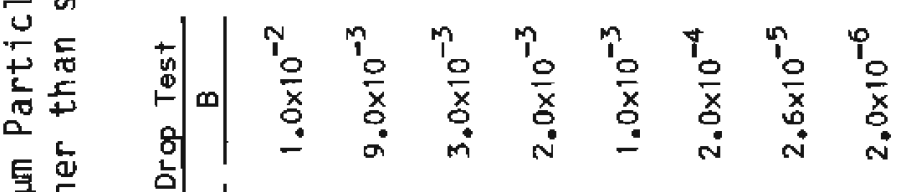

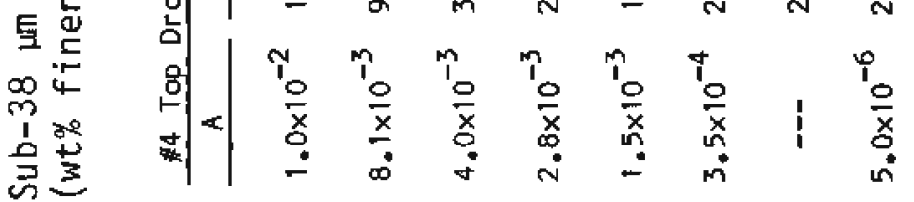

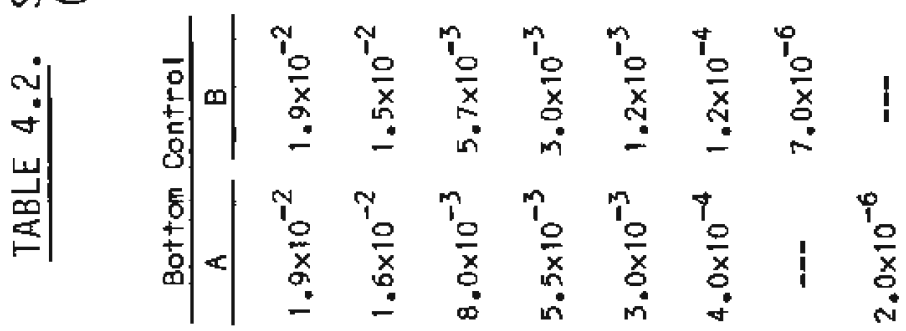

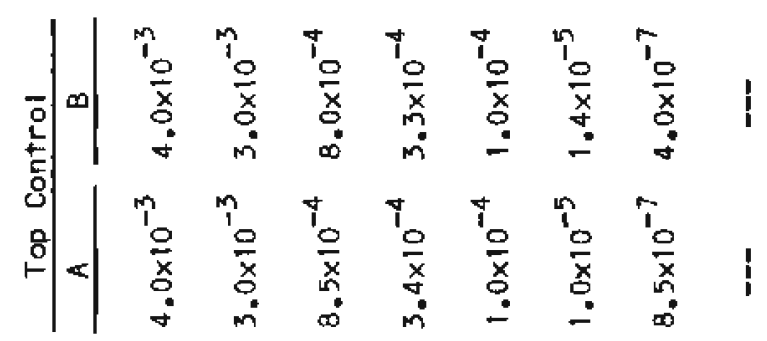

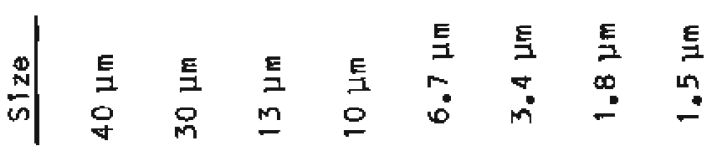




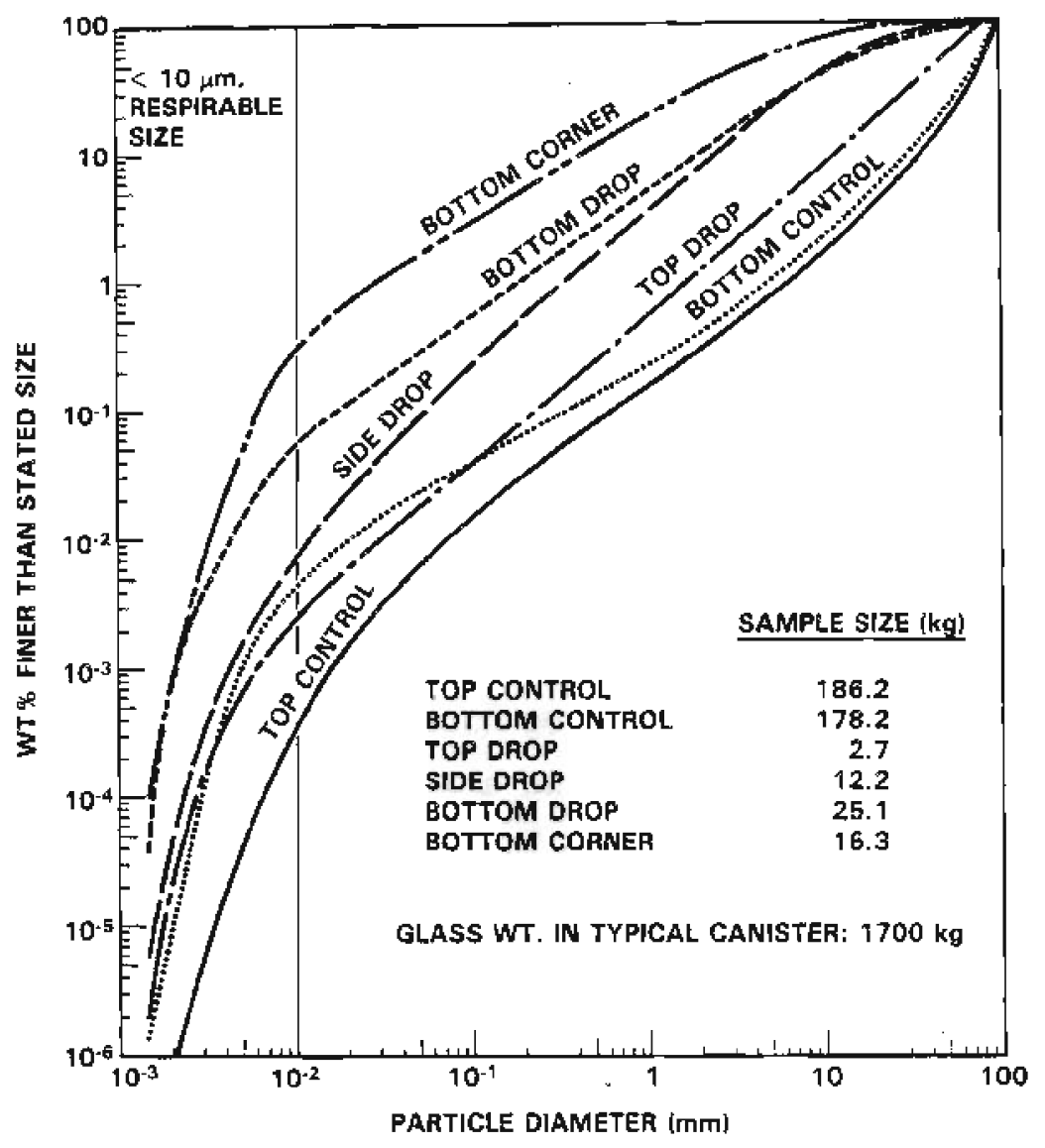

FIGURE 4.8. Glass Particle Size Distribution

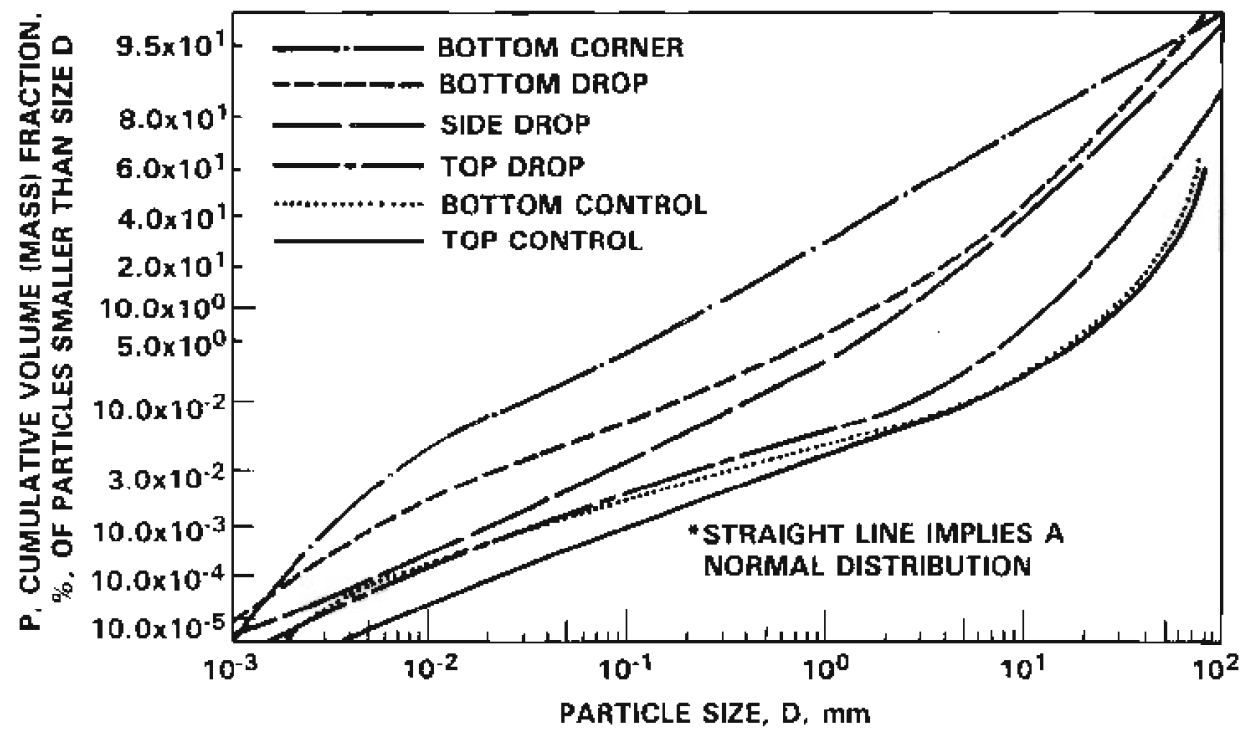

FIGURE 4.9. Log-Normal Plot of Glass Particle Size Distribution 
and represents the best fit to the variable data. As an example, this figure shows that for the bottom drop $0.05 \mathrm{wt} \%$ of the particles were less than $10^{-2}$ mri in diameter. For the control samples, a complete 2-foot section of glass was analyzed, whereas for the canisters that were dropped, the distributions were only in the damaged zones and were not normalized over the entire canister. Therefore, the size distributions for the canisters which were dropped are nigher than if they had been normalized over the entire canister. In determining the quantity of glass in the less than $10 \mu \mathrm{m}$ range that would result from an accidental impact, the entire canister should be considered. A summary of the glass analysis is shown in Table 4.3 . The actual damage zone ranges from $<1$ wto to 5 wt\% of the entire canister and the quantity of material less than 10 im was small. Figure 4.9 is a log-normal plot of the particle size distribution data. If the data falls along a straight line, the distribution of the particle sizes can be assumed to follow a nomal distribution and all normal statistical methods apply. This means the data can be conveniently interpolated or extrapolated to obtain size measurements beyond the 1 imited size range of the particular sieving measurements. In certain ranges, the data does appear to follow a straight line. Additional testing will be necessary to determine whether a11 the data follows a normal distribution. In order to obtain, with high confidence, the quantity of material at the sub-10 $\mu m$ range further testing will be required. This is the first group of data which has been collected using this SRL canister design.

\subsection{CANISTER DEFORMATION}

The canister deformation was measured by placing strain circles on the canisters in the impact area. The strain circles were deposited on the surface

TABLE 4.3. SRL Impact Tests Glass Analysis Summary

\begin{tabular}{|c|c|c|}
\hline Condition & Damage Zone & $\begin{array}{l}\text { Wt. of }<10 \text { un Fines } \\
\text { in Whole Canister }\end{array}$ \\
\hline As-Poured & $N / A$ & \\
\hline Side Drop & $1 \%$ & $5-75 \mathrm{~g}$ \\
\hline Top Drop & $<1 \%$ & \\
\hline Bottom Drop & $5 \%$ & $100-150 \mathrm{~g}$ \\
\hline
\end{tabular}


using an electrochemical processs analogous to preparing a contact print from a negative. Strain circles were placed on the canisters in the impact area of the nozzle, mid-line, and bottom. By measuring the circle diameters before and after the drops, the surface strains in the impact areas can be determined within $2 \%$ accuracy. Using the measured surface strains and comparing these strains with those reported in literature, the relative margin remaining before failure could occur can be determined. The initial circle diameters were nominally $5 \mathrm{~mm}(0.20 \mathrm{in.})$ and were arranged in a rectangular grid $6.35 \mathrm{~mm}$ (0.25 in.) from center to center. Each row and column of the grid was identified with a letter and number for reference. Figure 4.10 shows the strain circle grid. Strain circles were used instead of strain gauges because the strain circles are simple to use, cover a large area, are relatively inexpensive, and are accurate to within $2 \%$.

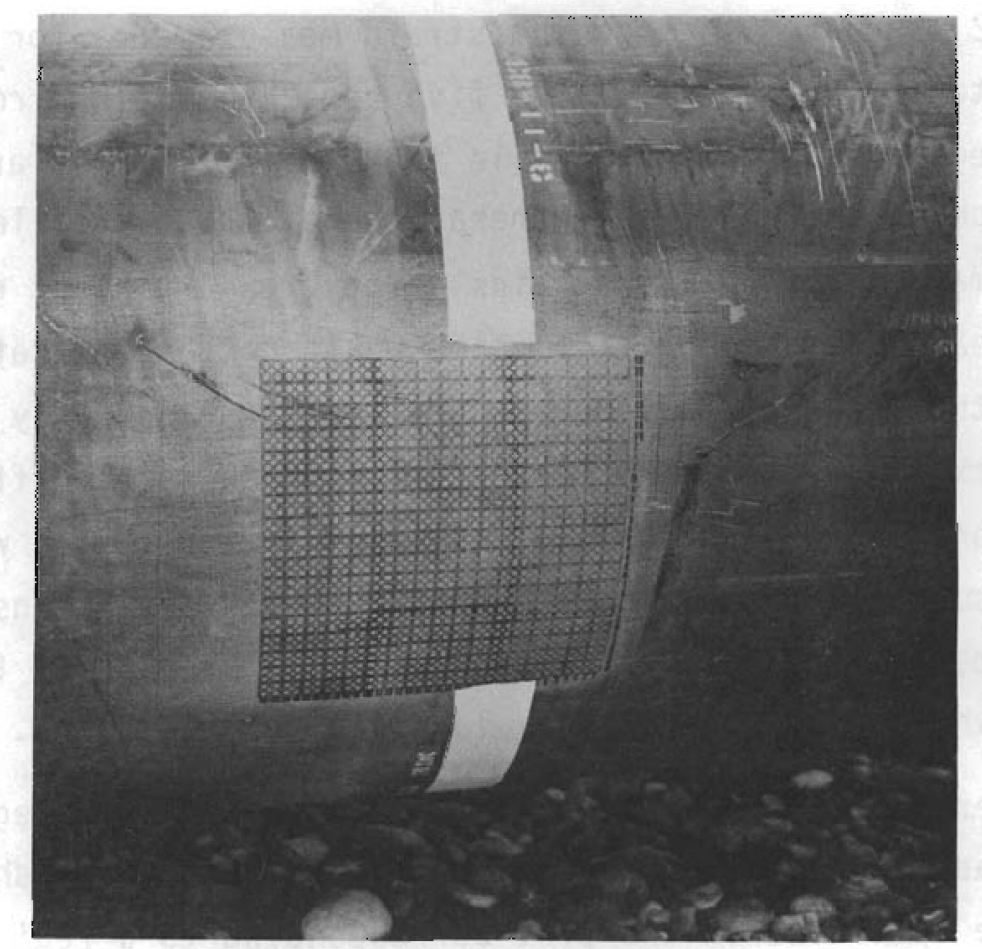

FIGURE 4.10. Strain Circle Grid on Canister Body 
Canister \#3 (titanium) had strain circles that were deformed during the top drop and bottom drop. Figure 4.11 shows the strain readings for the most severely deformed row of circles at the point of the bottom drop. Each plot represents a trace of strain as measured along a line starting on the canister body and progressing across the body to the bottom weld. The hoop direction corresponds to the direction going around the canister diameter. The axial direction corresponds to a line normal to the hoop direction and co-planar with the canister wall. Surface strains greater than zero are tensile strains while strains less than zero are compressive strains. For the bottom impact, the zero on the horizontal axis represents a point on the bottom weld. The maximum strains are $8 \%$. A tensile strain of at least $17 \%$ is reported for titanium as a typical strain level for failure to occur (Metals Handbook 1978). This indicates that the strain levels measured are below the levels at which failure could occur.

Figures 4.12 through 4.16 show the strain measurements for the nozzle region of the titanium canister for the five rows of strain circles that were closest to the region that failed. While the strain profiles are silightly different for each of the rows, the general shape of the profiles are similar and the maximum magnitudes of the strains in any row are about equal. The maximum strain measured was about $14 \%$ which would not be indicative of a tensile failure of the material. Higher strain levels undoubtedly were present closer to the neck. However, this region was not accessible after the drop due to the deformation. Also, the failure, at least in the region where the strains were measured, was a tearing mode failure and not a tensile failure. once the tear had developed, it propagated through a region of fairly modest tensile strains while causing only very localized high strains.

With canister \#4, the strain circles were measured in a region that ran from near the head to body weld toward the neck. The data is shown in Figure 4.17 with the left side of the plot corresponding to a region nearest the body. The highest strain levels were about $12 \%$. This was less than that measured for the titanium canister which ruptured. However, the deformation mode of canister \#4 resulted in mostly bending and tensile strains and a tearing mode of failure did not develop. The region of highest strain was at the 


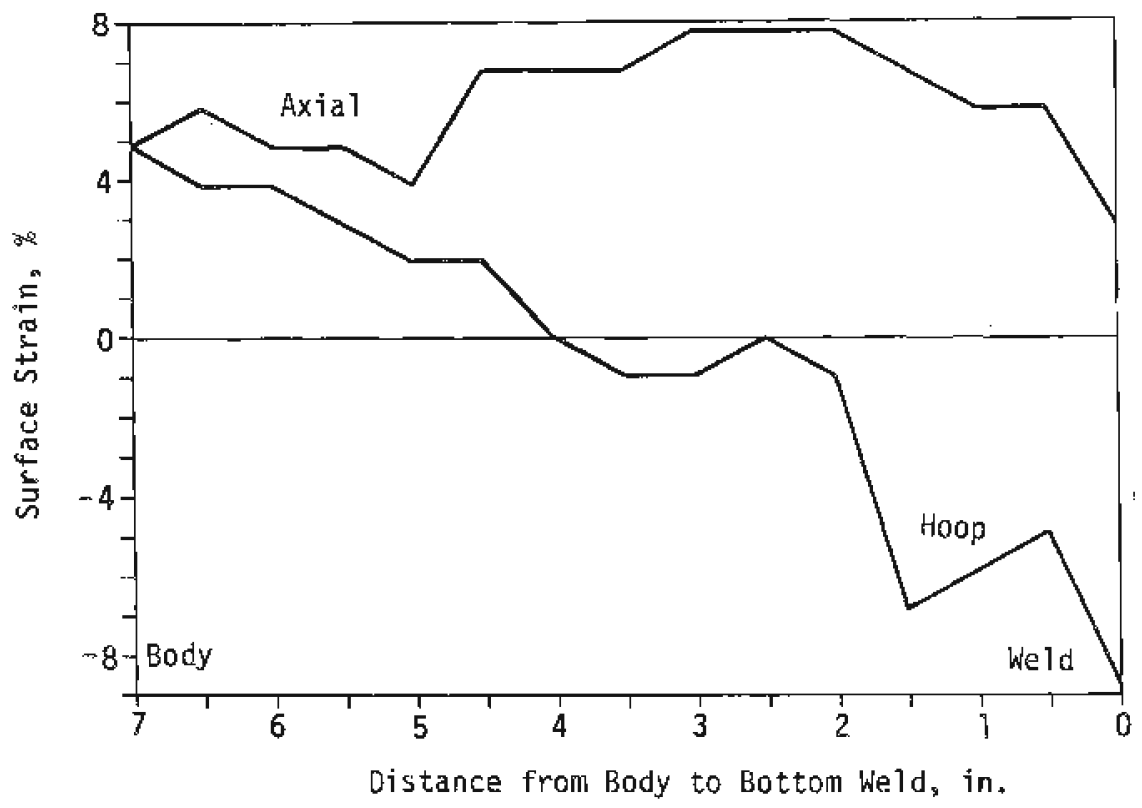

FIGURE 4.11. Strain Levels for the Titanium Canister for the Bottom Impact

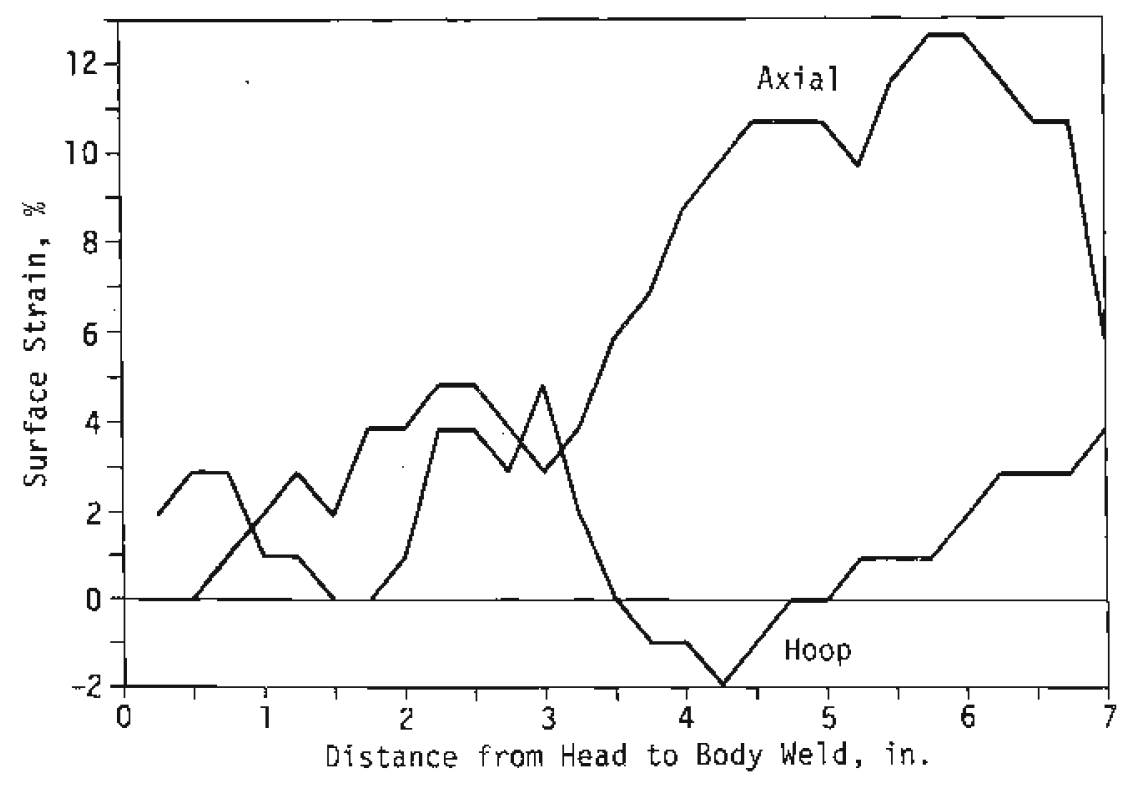

FIGURE 4.12. Strain Levels for the Titanium Canister for Strain Circle Rows about 1.25 in. from Tear 


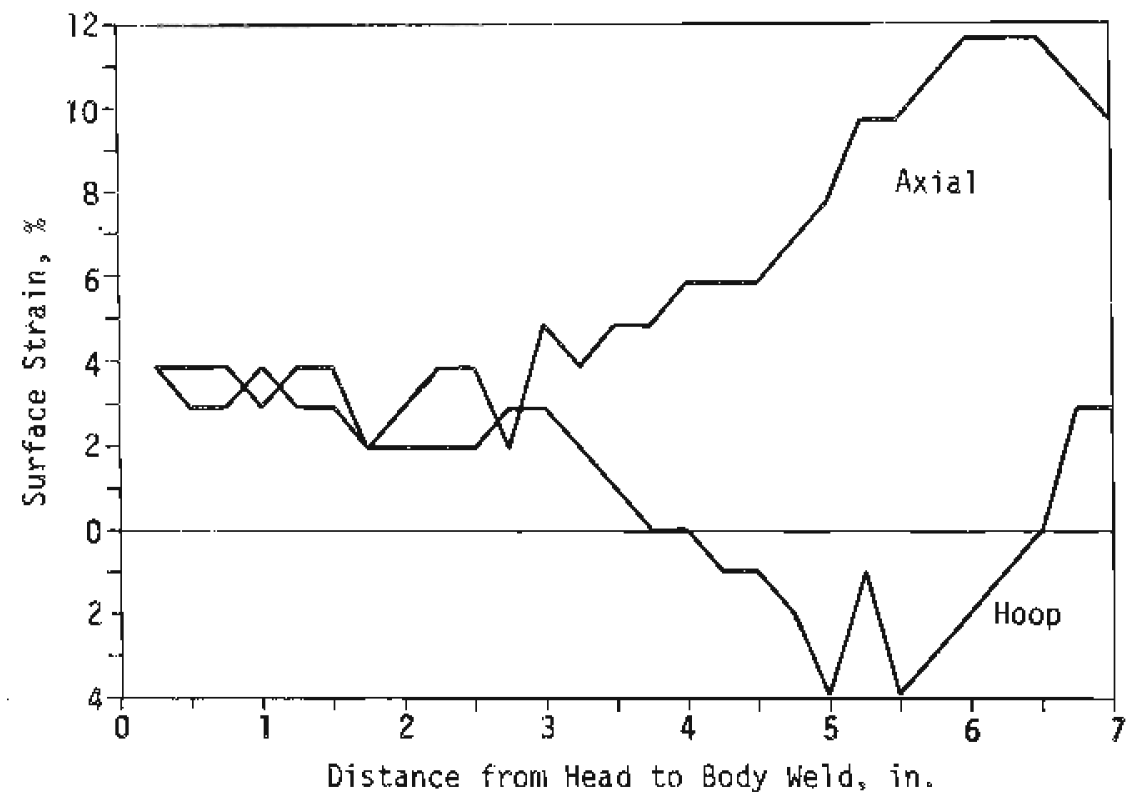

FIGURE 4.13. Strain Levels for the Titanfum Canister for Strain Circle Rows About 1.0 in. from Tear

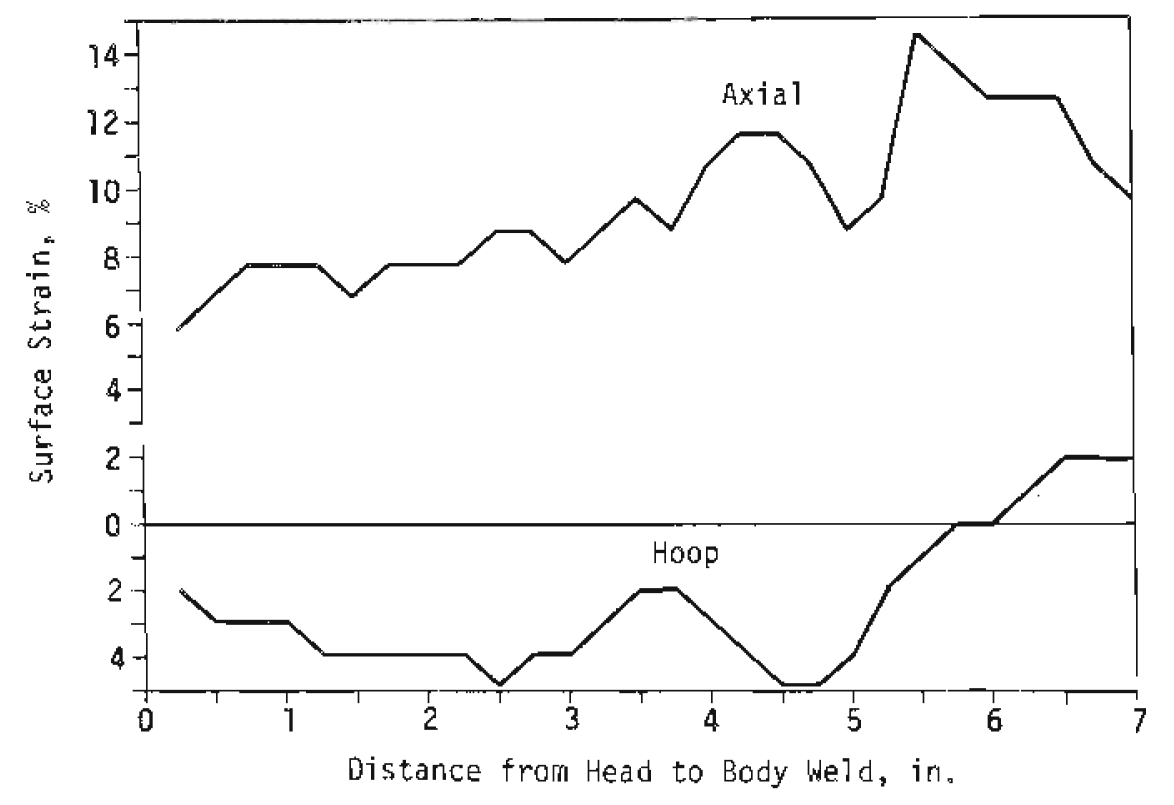

FIGURE 4.14. Strain Levels for the Titanium Canister for Strain Circle Rows About 0.75 in. from Tear 


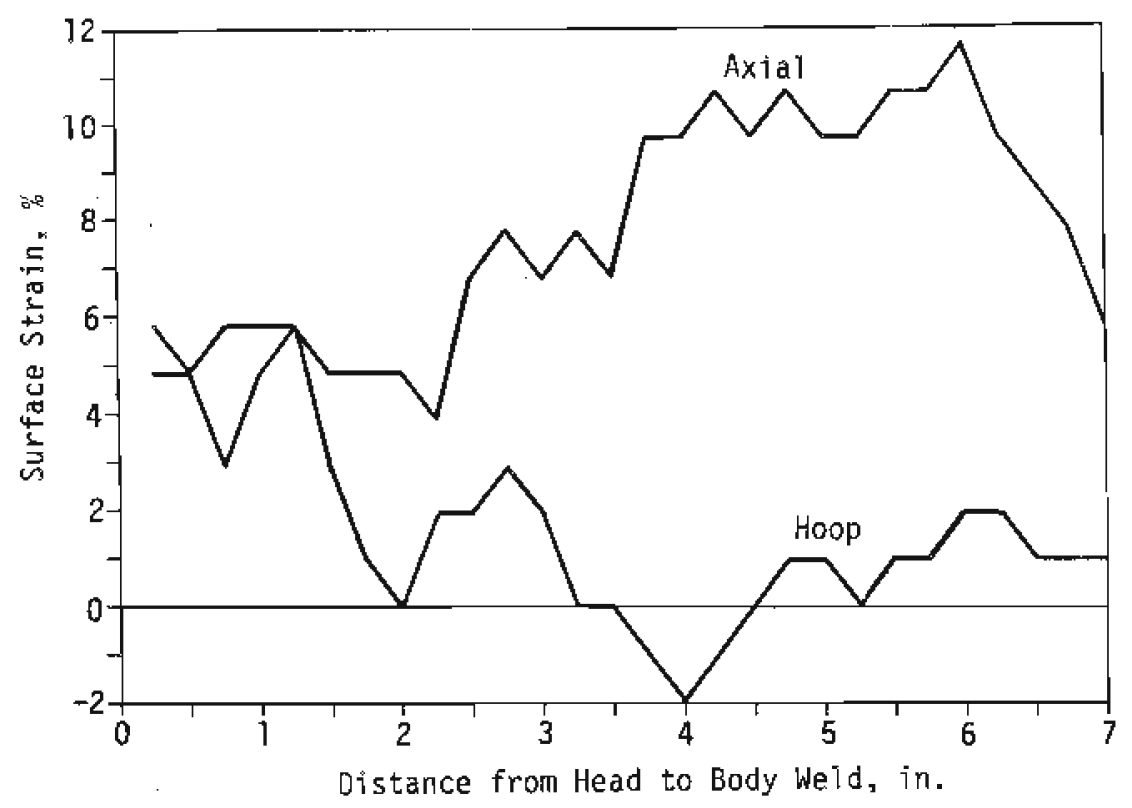

FIGURE 4.15. Strain Levels for the Titanium Canister for Strain Circle Rows About 0.5 in. from Tear

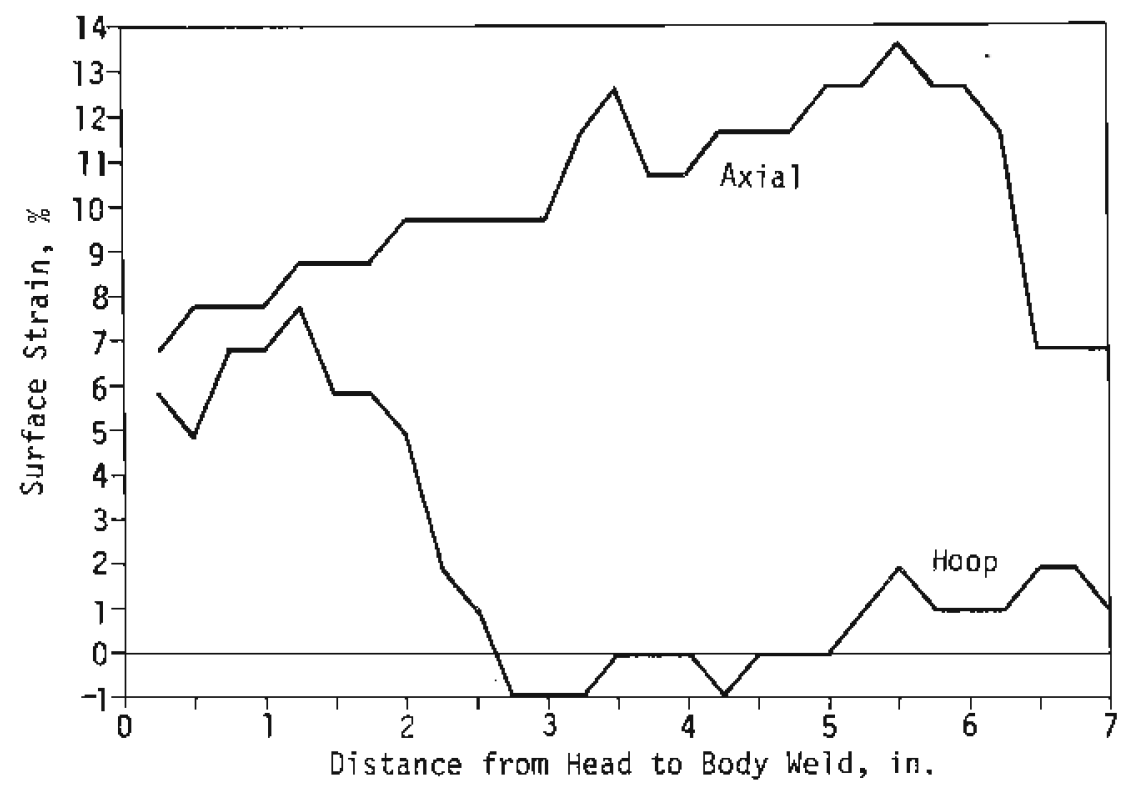

FIGURE 4.16. Strain Levels for the Titanium Canister for Strain Circle Rows About 0.25 in. from Tear 


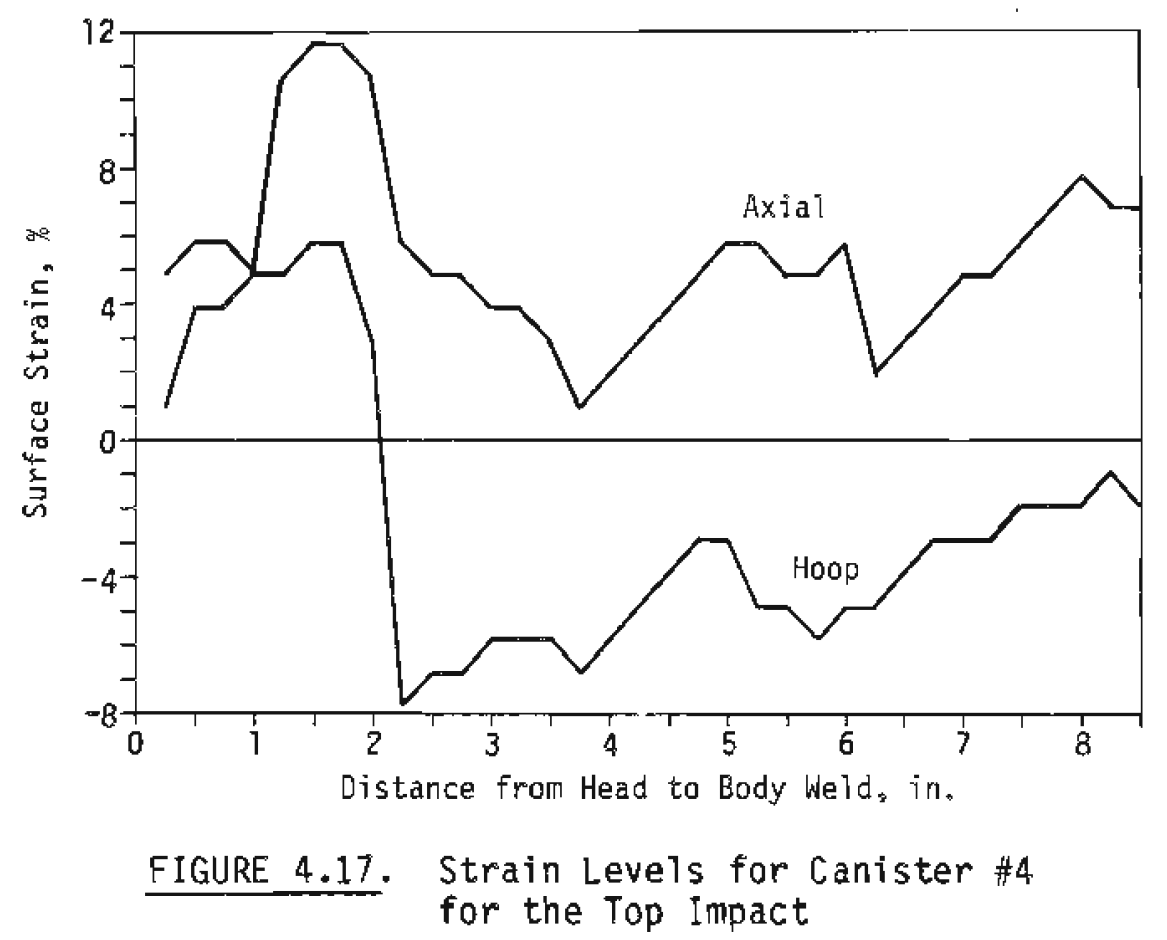

shoulder of the head where contact was made with the drop pad. Since it was not possible to read the strain circles all the way to the neck, levels of higher strain may have been present in that region because more deformation occurred in the neck area. The strains measured were still well below the typical strain failure level of $56 \%$ (Metals Handbook, 1978).

Canister \#5 was subjected to both a bottom and side drop. Figure 4.18 shows the results of the side drop. Maximum strain levels were about $14 \%$. Figure 4.19 shows the strain measurements for the canister in the region of the bottom to body weld. While the canister experienced noticeable deformations in this region, the strain levels were well below the $56 \%$ level and a much more severe drop would be required for a rupture to occur. 


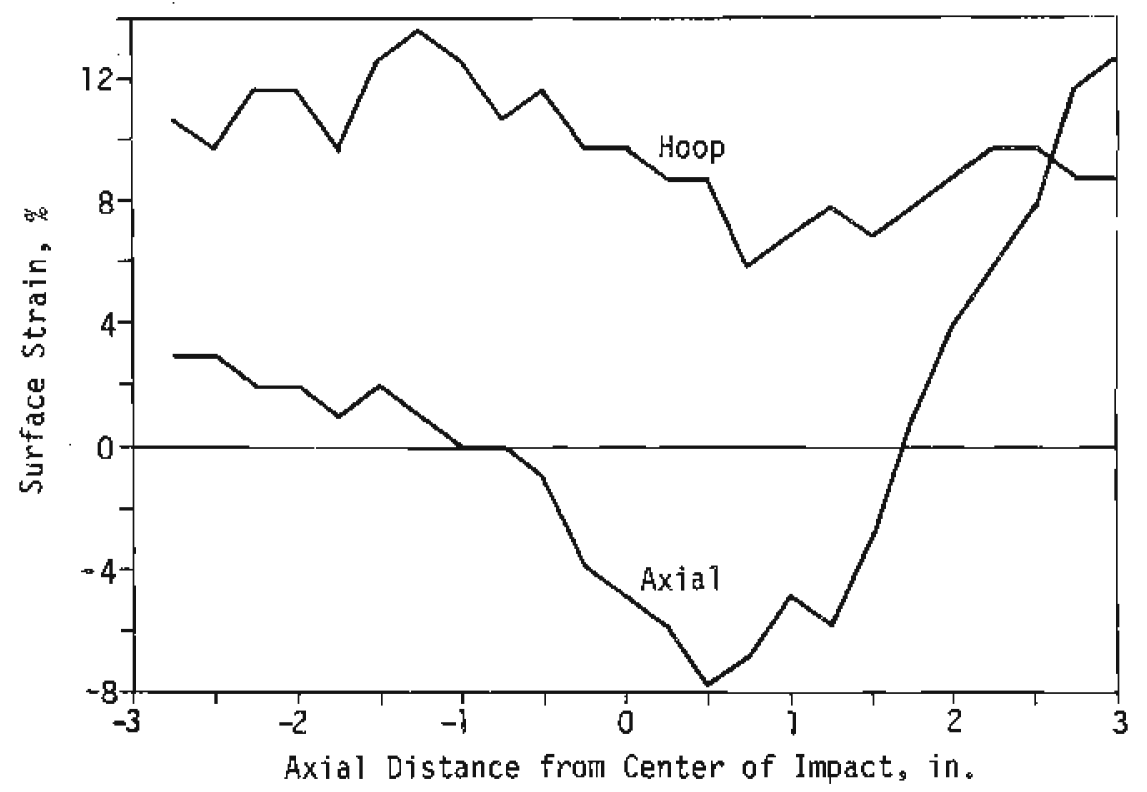

FIGURE 4.18. Strain Levels for Canister \#5 for the Side Impact

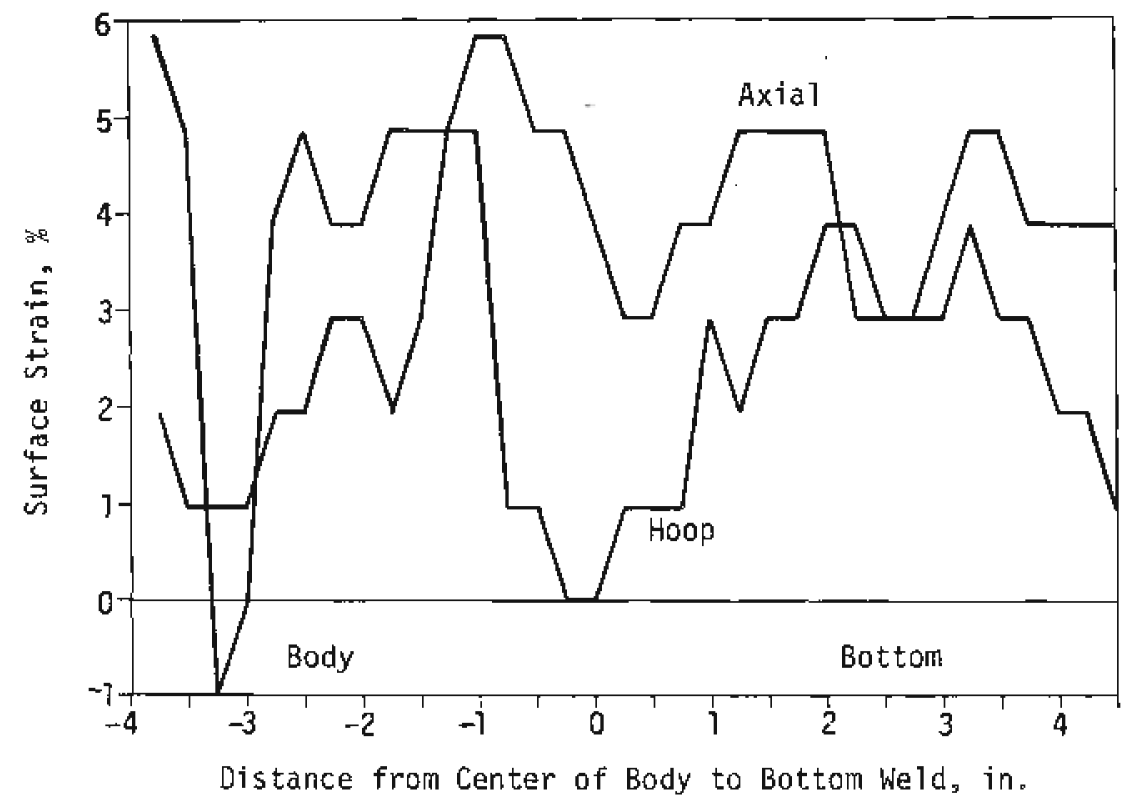

FIGURE 4.19. Strain Levels for Canister \#5 for the Bottom Impact 


\subsection{REFERENCES}

ASM Handbook Committee. 1978. Metals Handbook, 9th edition, Vo1, 3, p. 409, 757. American Society for Metals, Metals Park, Ohio.

Baxter, R. G. 1983. Description of Defense Waste Processing Facility Reference Waste Form and Canister. DP-1606, Rev. 1. Savannah River Laboratory, Aiken, South Carolina.

Office of Nuclear Waste Isolation (ONWI). 1983. Conceptual Waste Package Interim Product Specifications and Data Requirements for Disposal of Glass Commercial High-Level Waste Forms in Salt Geologic Repositories. BMI/ONWI-521. Battelle Memorial Institute, Columbus, Ohio. 


\section{DISTRIBUTION}

No. of

Copies

OFFSITE

27 Technical Information Center

2 DOE Office of Defense Waste and Byproducts Mariagement

GTN

W'ashington, DC 20545

ATTN: J. J. Jicha, DP-123

D. B. Leclaire, OP-12

2 EG\&G Idaho, Inc.

P.0. Box 1625

Idaho Fal1s, I0 83415

ATTN: R. Y. Maughn

R. M. Neilson, Jr.

3 E. I. du Pont de Nemours \& Co. Savannah River Laboratory

Aiken, SC 29801

ATTH: R. G. Baxter

E. J. Hennelly

J. N. Kelker

4 Sandia National Laboratory Transportation Systems Development and Testing Division

Albuquerque, NM 87185

ATTN: G. A1len, 0rg. 6323

M. M. Madsen, Org. 6323

M. Molecke, Org. 6321

R. Sandeval, org. 6321

2 J. Proietti

DOE Savannan River Operations Office

P.0. Biox A

Aiken, SC 29801

E. L. Wilmot

DOE Sandia Laboratory Operations office

A1buquerque, M 87185

Beverly Rawles

BMI - Library

505 King Avenue

Col umbus, OH 43210
Wo. of

Coptes

3 West Valley Nuclear Services Co., Inc.

P.0. Box 191

West Valley, NY 14171-0191

ATTH: C. C, Chapman

J. M. Pope

'A. G. Richmond

J. D. Hurley

ThSo/Rocky Flats Plant

Rockwell international Corp.

P. 0. Box 464

Golden, 6080401

\section{ONSITE}

4 Richland Operations office

E. A. Brachen

H. E. Ransom

M. L. Shupe

J. D. White

Rockwell Hanford Operations

N. A. Hertelendy

36 Pacific Northwest Laboratory

J. M. A7 zheimer

N. F. Bonner

H. C. Burkholder

J. R. Carrel1

T. D. Chikalla

J. R. Friley

L. K. Hol ton

R. F, Klein

J. L. McEl roy

J. E. Mendel

M. D. Merz

J. E. Minor

M. E. Peterson (10)

P. A. Scott

5. C. Slate (5)

1. W. Thielman

Publishing Coordination (2)

Techrical Infomation (5) 